\title{
Growing knowledge: an overview of Seed Plant diversity in Brazil
}

\author{
The Brazil Flora Group
}

Recommended citation: BFG (2015).

This paper was compiled by Daniela C. Zappi ${ }^{1}$, Fabiana L. Ranzato Filardi, Paula Leitman, Vinícius C. Souza, Bruno M.T. Walter, José R. Pirani, Marli P. Morim, Luciano P. Queiroz, Taciana B. Cavalcanti, Vidal F. Mansano and Rafaela C. Forzza ${ }^{1}$

With contributions by: Abreu, Maria C.; Acevedo-Rodríguez, Pedro; Agra, Maria F.; Almeida Jr., Eduardo B.; Almeida, Gracineide S.S.; Almeida, Rafael F.; Alves, Flávio M.; Alves, Marccus; Alves-Araujo, Anderson; Amaral, Maria C.E.; Amorim, André M.; Amorim, Bruno; Andrade, Ivanilza M.; Andreata, Regina H.P.; Andrino, Caroline O.; Anunciação, Elisete A.; Aona, Lidyanne Y.S.; Aranguren, Yani; Aranha Filho, João L.M.; Araújo, Andrea O.; Araújo, Ariclenes A.M.; Araújo, Diogo; Arbo, María M.; Assis, Leandro; Assis, Marta C.; Assunção, Vivian A.; AthiêSouza, Sarah M.; Azevedo, Cecilia O.; Baitello, João B.; Barberena, Felipe F.V.A.; Barbosa, Maria R.V.; Barros, Fábio; Barros, Lucas A.V.; Barros, Michel J.F.; Baumgratz, José F.A.; Bernacci, Luis C.; Berry, Paul E.; Bigio, Narcísio C.; Biral, Leonardo; Bittrich, Volker; Borges, Rafael A.X.; Bortoluzzi, Roseli L.C.; Bove, Cláudia P.; Bovini, Massimo G.; Braga, João M.A.; Braz, Denise M.; Bringel Jr., João B.A.; Bruniera, Carla P.; Buturi, Camila V.; Cabral, Elza; Cabral, Fernanda N.; Caddah, Mayara K.; Caires, Claudenir S.; Calazans, Luana S.B.; Calió, Maria F.; Camargo, Rodrigo A.; Campbell, Lisa; Canto-Dorow, Thais S.; Carauta, Jorge P.P.†; Cardiel, José M.; Cardoso, Domingos B.O.S.; Cardoso, Leandro J.T.; Cameiro, Camila R.; Carneiro, Cláudia E.; Carneiro-Torres, Daniela S.; Carrijo, Tatiana T.; Caruzo, Maria B.R.; Carvalho, Maria L.S.; Carvalho-Silva, Micheline; Castello, Ana C.D.; Cavalheiro, Larissa; Cervi, Armando C.ț; Chacon, Roberta G.; Chautems, Alain; Chiavegatto, Berenice; Chukr, Nádia S.; Coelho, Alexa A.O.P.; Coelho, Marcus A.N.; Coelho, Rubens L.G.; Cordeiro, Inês; Cordula, Elizabeth; Cornejo, Xavier; Côrtes, Ana L.A.; Costa, Andrea F.; Costa, Fabiane N.; Costa, Jorge A.S.; Costa, Leila C.; Costa-e-Silva, Maria B.; Costa-Lima, James L.; Cota, Maria R.C.; Couto, Ricardo S.; Daly, Douglas C.; De Stefano, Rodrigo D.; De Toni, Karen; Dematteis, Massimiliano; Dettke, Greta A.; Di Maio, Fernando R.; Dórea, Marcos C.; Duarte, Maŕlia C.; Dutilh, Julie H.A.; Dutra, Valquíria F.; Echternacht, Livia; Eggers, Lilian; Esteves, Gerleni; Ezcurra, Cecilia; Falcão Junior, Marcus J.A.; Feres, Fabíola; Fernandes, José M.; Ferreira, D.M.C.; Ferreira, Fabrício M.; Ferreira, Gabriel E.; Ferreira, Priscila P.A.; Ferreira, Silvana C.; Ferrucci, Maria S.; Fiaschi, Pedro; Filgueiras, Tarciso S.; Firens, Marcela; Flores, Andreia S.; Forero, Enrique; Forster, Wellington; Fortuna-Perez, Ana P.; Fortunato, Reneé H.; Fraga, Cláudio N.; França, Flávio; Francener, Augusto; Freitas, Joelcio; Freitas, Maria F.; Fritsch, Peter W.; Furtado, Samyra G.; Gaglioti, André L.; Garcia, Fávia C.P.; Germano Filho, Pedro; Giacomin, Leandro; Gil, André S.B.; Giulietti, Ana M.; Godoy, Silvana A.P. ; Goldenberg, Renato; Gomes da Costa, Géssica A.; Gomes, Mário; Gomes-Klein, Vera L.; Gonçalves, Eduardo Gomes; Graham, Shirley; Groppo, Milton; Guedes. Juliana S.; Guimarães, Leonardo R.S.; Guimarães, Paulo J.F.; Guimarães, Elsie F.; Gutierrez, Raul; Harley, Raymond; Hassemer, Gustavo; Hattori, Eric K.O.; Hefler, Sonia M.; Heiden, Gustavo; Henderson, Andrew; Hensold, Nancy; Hiepko, Paul; Holanda, Ana S.S.; Iganci, João R.V.; Imig, Daniela C.; Indriunas, Alexandre; Jacques, Eliane L.; Jardim, Jomar G.; Kamer, Hiltje M.; Kameyama, Cintia; Kinoshita, Luiza S.; Kirizawa, Mizué; Klitgaard, Bente B.; Koch, Ingrid; Koschnitzke, Cristiana; Krauss, Nathália P.; Kriebel, Ricardo; Kuntz, Juliana; Larocca, João; Leal, Eduardo S.; Lewis, Gwilym P.; Lima, Carla 
T.; Lima, Haroldo C.; Lima, Itamar B.; Lima, Laíce F.G.; Lima, Laura C.P.; Lima, Leticia R.; Lima, Luís F.P.; Lima, Rita B.; Lírio, Elton J.; Liro, Renata M.; Lleras, Eduardo†; Lobão, Adriana; Loeuille, Benoit; Lohmann, Lúcia G.; Loiola, Maria I.B.; Lombardi, Julio A.; Longhi-Wagner, Hilda M.; Lopes, Rosana C.; Lorencini, Tiago S.; Louzada, Rafael B.; Lovo, Juliana; Lozano, Eduardo D.; Lucas, Eve; Ludtke, Raquel; Luz, Christian L.; Maas, Paul; Machado, Anderson F.P.; Macias, Leila; Maciel, Jefferson R.; Magenta, Mara A.G.; Mamede, Maria C.H.; Manoel, Evelin A.; Marchioretto, Maria S.; Marques, Juliana S.; Marquete, Nilda; Marquete, Ronaldo; Martinelli, Gustavo; Martins da Silva, Regina C.V.; Martins, Ângela B.; Martins, Erika R.; Martins, Márcio L.L.; Martins, Milena V.; Martins, Renata C.; Matias, Ligia Q.; Maya-L., Carlos A.; Mayo, Simon; Mazine, Fiorella; Medeiros, Debora; Medeiros, Erika S.; Medeiros, Herison; Medeiros, João D.; Meireles, José E.; Mello-Silva, Renato; Melo, Aline; Melo, André L.; Melo, Efigênia; Melo, José I.M.; Menezes, Cristine G.; Menini Neto, Luiz; Mentz, Lilian A.; Mezzonato, A.C.; Michelangeli, Fabián A.; Milward-de-Azevedo, Michaele A.; Miotto, Silvia T.S.; Miranda, Vitor F.O.; Mondin, Cláudio A.; Monge, Marcelo; Monteiro, Daniele; Monteiro, Raquel F.; Moraes, Marta D.; Moraes, Pedro L.R.; Mori, Scott A.; Mota, Aline C.; Mota, Nara F.O.; Moura, Tania M.; Mulgura, Maria; Nakajima, Jimi N.; Nardy, Camila; Nascimento Júnior, José E.; Noblick, Larry; Nunes, Teonildes S.; O'Leary, Nataly; Oliveira, Arline S.; Oliveira, Caetano T.; Oliveira, Juliana A.; Oliveira, Luciana S.D.; Oliveira, Maria L.A.A.; Oliveira, Regina C.; Oliveira, Renata S.; Oliveira, Reyjane P.; Paixão-Souza, Bruno; Parra, Lara R.; Pasini, Eduardo; Pastore, José F.B.; Pastore, Mayara; Paula-Souza, Juliana; Pedemeiras, Leandro C.; Peixoto, Ariane L.; Pelissari, Gisela; Pellegrini, Marco O.O.; Pennington, Toby; Perdiz, Ricardo O.; Pereira, Anna C.M.; Pereira, Maria S.; Pereira, Rodrigo A.S.; Pessoa, Clenia; Pessoa, Edlley M.; Pessoa, Maria C.R.; Pinto, Luiz J.S.; Pinto, Rafael B.; Pontes, Tiago A.; Prance, Ghillean T.; Proença, Carolyn; Profice, Sheila R.; Pscheidt, Allan C.; Queiroz, George A.; Queiroz, Rubens T.; Quinet, Alexandre; Rainer, Heimo; Ramos, Eliana; Rando, Juliana G.; Rapini, Alessandro; Reginato, Marcelo; Reis, Ilka P.; Reis, Priscila A.; Ribeiro, André R.O.; Ribeiro, José E.L.S.; Riina, Ricarda; Ritter, Mara R.; Rivadavia, Fernando; Rocha, Antônio E.S.; Rocha, Maria J.R.; Rodrigues, Izabella M.C.; Rodrigues, Karina F.; Rodrigues, Rodrigo S.; Rodrigues, Rodrigo S.; Rodrigues, Vinícius T.; Rodrigues, William; Romaniuc Neto, Sérgio; Romão, Gerson O.; Romero, Rosana; Roque, Nádia; Rosa, Patrícia; Rossi, Lúcia; Sá, Cyl F.C.; Saavedra, Mariana M.; Saka, Mariana; Sakuragui, Cássia M.; Salas, Roberto M.; Sales, Margareth F.; Salimena, Fatima R.G.; Sampaio, Daniela; Sancho, Gisela; Sano, Paulo T.; Santos, Alessandra; Santos, Élide P.; Santos, Juliana S.; Santos, Marianna R.; Santos-Gonçalves, Ana P.; Santos-Silva, Fernanda; São-Mateus, Wallace; Saraiva, Deisy P.; Saridakis, Dennis P.; Sartori, Ângela L.B.; Scalon, Viviane R.; Schneider, Ângelo; Sebastiani, Renata; Secco, Ricardo S.; Senna, Luisa; Senna-Valle, Luci; Shirasuna, Regina T.; Silva Filho, Pedro J.S.; Silva, Anádria S.; Silva, Christian; Silva, Genilson A.R.; Silva, Gisele O.; Silva, Márcia C.R.; Silva, Marcos J.; Silva, Marcos J.; Silva, Otávio L.M.; Silva, Rafaela A.P.; Silva, Saura R.; Silva, Tania R.S.; Silva-Gonçalves, Kelly C.; Silva-Luz, Cintia L.; Simão-Bianchini, Rosângela; Simões, André O.; Simpson, Beryl; Siniscalchi, Carolina M.; Siqueira Filho, José A.; Siqueira, Carlos E.; Siqueira, Josafá C.; Smith, Nathan P.; Snak, Cristiane; Soares Neto, Raimundo L.; Soares, Kelen P.; Soares, Marcos V.B.; Soares, Maria L.; Soares, Polyana N.; Sobral, Marcos; Sodré, Rodolfo C.; Somner, Genise V.; Sothers, Cynthia A.; Sousa, Danilo J.L.; Souza, Elnatan B.; Souza, Élvia R.; Souza, Marcelo; Souza, Maria L.D.R.; Souza-Buturi, Fátima O.; Spina, Andréa P.; Stapf, María N.S.; Stefano, Marina V.; Stehmann, João R.; Steinmann, Victor; Takeuchi, Cátia; Taylor, Charlotte M.; Taylor, Nigel P.; Teles, Aristônio M.; Temponi, Livia G.; Terra-Araujo, Mário H.; Thode, Veronica; Thomas, W.Wayt; Tissot-Squalli, Mara L.; Torke, Benjamin M.; Torres, Roseli B.; Tozzi, Ana M.G.A.; Trad, Rafaela J.; Trevisan, Rafael; Trovó, Marcelo; Valls, José F.M.; Vaz, 
Angela M.S.F.; Versieux, Leonardo; Viana, Pedro L.; Vianna Filho, Marcelo D.M.; Vieira, Ana O.S.; Vieira, Diego D.; Vignoli-Silva, Márcia; Vilar, Thaisa; Vinhos, Franklin; Wallnöfer, Bruno; Wanderley, Maria G.L.; Wasshausen, Dieter; Watanabe, Maurício T.C.; Weigend, Maximilian; Welker, Cassiano A.D.; Woodgyer, Elizabeth; Xifreda, Cecilia C.; Yamamoto, Kikyo; Zanin, Ana; Zenni, Rafael D.; Zickel, Carmem S.

\begin{abstract}
An updated inventory of Brazilian seed plants is presented and offers important insights into the country's biodiversity. This work started in 2010, with the publication of the Plants and Fungi Catalogue, and has been updated since by more than 430 specialists working online. Brazil is home to 32,086 native Angiosperms and 23 native Gymnosperms, showing an increase of $3 \%$ in its species richness in relation to 2010. The Amazon Rainforest is the richest Brazilian biome for Gymnosperms, while the Atlantic Rainforest is the richest one for Angiosperms. There was a considerable increment in the number of species and endemism rates for biomes, except for the Amazon that showed a decrease of $2.5 \%$ of recorded endemics. However, well over half of Brazillian seed plant species $(57.4 \%)$ is endemic to this territory. The proportion of life-forms varies among different biomes: trees are more expressive in the Amazon and Atlantic Rainforest biomes while herbs predominate in the Pampa, and lianas are more expressive in the Amazon, Atlantic Rainforest, and Pantanal. This compilation serves not only to quantify Brazilian biodiversity, but also to highlight areas where there information is lacking and to provide a framework for the challenge faced in conserving Brazil's unique and diverse flora.
\end{abstract}

Key words: Angiosperms, biomes, endemism, Gymnosperms, life-forms.

\title{
Resumo
}

Um levantamento atualizado das plantas com sementes e análises relevantes acerca desta biodiversidade são apresentados. Este trabalho se iniciou em 2010 com a publicação do Catálogo de Plantas e Fungos e, desde então vem sendo atualizado por mais de 430 especialistas trabalhando online. O Brasil abriga atualmente 32.086 espécies nativas de Angiospermas e 23 espécies nativas de Gimnospermas e estes novos dados mostram um aumento de 3\% da riqueza em relação a 2010. A Amazônia é o Domínio Fitogeográfico com o maior número de espécies de Gimnospermas, enquanto que a Floresta Atlântica possui a maior riqueza de Angiospermas. Houve um crescimento considerável no número de espécies e nas taxas de endemismo para a maioria dos Domínios (Caatinga, Cerrado, Floresta Atlântica, Pampa e Pantanal), com exceção da Amazônia que apresentou uma diminuição de 2,5\% de endemicidade. Entretanto, a maior parte das plantas com sementes que ocorrem no Brasil (57,4\%) é endêmica deste território. A proporção de formas de vida varia de acordo com os diferentes Domínios: árvores são mais expressivas na Amazônia e Floresta Atlântica do que nos outros biomas, ervas são dominantes no Pampa e as lianas apresentam riqueza expressiva na Amazônia, Floresta Atlântica e Pantanal. Este trabalho não só quantifica a biodiversidade brasileira, mas também indica as lacunas de conhecimento e o desafio a ser enfrentado para a conservação desta flora.

Palavras-chave: Angiospermas, Domínios, endemismo, formas de vida, Gimnospermas.

\section{Introduction}

The Global Strategy for Plant Conservation (GSPC), adopted by the Conference of the Parties of the Convention's signatory countries on Biological Diversity (CBD), held at The Hague, Holland, in 2002, set 16 targets to be achieved globally by 2010. The first target, vital to the completion of all others, was the development of a functional, widely accessible list of all known plant species, as a first step towards a complete World Flora. In 2008, the Botanical Garden of Rio de Janeiro was designated by the Ministry of Environment to coordinate the preparation of the Species List of the Brazilian Flora. The Botanical Garden of Rio de Janeiro invited botanists from several Brazilian institutions to constitute the project's Steering Committee.

For the complete list of authors, institutions and taxonomic groups see supplementary material $<$ http://dx.doi.org/10.6084/m9.figshare.1531952> DOI: 10.1590/2175-7860201566411.

\footnotetext{
${ }^{1}$ Authors for correspondence: d.zappi@kew.org, rafaela@jbrj.gov.br
} 
Target 1 of the GSPC was reached by Brazil in 2010 with the launch of the first on-line version of the List of Flora of Brazil and the publication of Plants and Fungi Catalogue.

Awareness of the threats faced by the world's biodiversity has risen considerably since the $1980 \mathrm{~s}$ (Myers et al. 2000; Mittermeier et al. 2004). Brazil is at the center of this discussion, as it includes two of the 34 recognized global hotspots, housing a larger number of plant species than any other country in the world (Mittermeier et al. 2004; Forzza et al. 2012). With an economy strongly driven by large scale agriculture, mining of its natural resources, and growing urban population, large tracts of the country's natural reserves are being depleted, even before our knowledge can ascertain what is being lost.

The Flora brasiliensis (Martius et al. 1833; Urban 1906) treatment listed 19,958 species of fungi, algae, mosses and vascular plants, including 18,857 seed plants. After that, botanical knowledge expanded inordinately as new species were described and names were synonymized through floristic and monographic accounts. There have been both conservative and generous estimates for the size of the seed plant component of the Brazilian Flora (Forzza et al. 2012), and, while the 2010 list, dealing only with described plant diversity, did not reach the more conservative published estimate $(35,664$ species) and is very far from the exaggerated $(45,015$ species $)$ ones, it still surpassed the number of plants known thus far in any other country in the world. The Brazilian Catalogue of Plants and Fungi reported 31,188 species of seed plants, distributed in 2,818 genera and 227 families of Angiosperms (Forzza et al. 2010) and 23 species in six genera and five families of Gymnosperms (Souza 2010).

Five years have elapsed from the first release of the Brazilian on-line list and the addition of new facilities have enabled botanists to contribute further information regarding species habit, substrate and vegetation types, as well as continuing to refine the existing list and adding new records and taxa. Here we provide a snapshot of the changes to the Brazilian List during this period, and also analyse new data that have come to light at the end of this process, providing a fresh insight into seed plant species numbers, endemism and distribution patterns, as well as proportions of life-forms and richness throughout the main habitats of this megadiverse country.

\section{Methods}

The methodology followed the principles established for all plant and fungi groups catalogued by Forzza et al. (2010). The minimum Species 2000 fields were adopted and increased with others (geopolitical divisions, biomes etc.) that were interesting to feature for the Brazilian context, and the design and development of an information system that allowed instant management, collaborative updating of the data and generation of the 2010 Catalogue (Forzza et al. 2010). The work took place in two phases. The first one included analysis, harmonization and importation of diverse state and regional lists and taxonomic treatments already available (see Forzza et al. 2010 for a complete list), while the second phase was the revision and updating of the information relative to each taxon made directly on-line by 334 specialists.

From 2011 the contributors continued with the task of including new records and modifying existent ones as more scientific data became available. Yearly releases of the system comprised new fields and dictionaries to include data regarding life-forms, substrate and vegetation type for each taxon that needed to be completed, and a new functionality to include images meant that the researchers could, from that point onwards, choose images from herbarium records and make available their own images of living plants. At the end of 2014 the Angiosperm and Gymnosperm coordinators complemented data in families where data were still missing. During the three first months of 2015 a data evaluation process generated a series of reports indicating inconsistencies aimed to help the 437 contributors to further clean the data. The corrections were added in March 2015. For more information about the final dataset see supplementary material $<$ http://dx.doi.org/10.6084/m9.figshare.1538647> - DOI: 10.1590/2175-7860201566411.

From the start of the project, the importance to distinguish between native and exotic species was highlighted, and the contributing specialists had to complete an 'Origin' field with the following options: native, naturalized and cultivated. Moro et al. (2012) clearly states different categories for exotic species and analyses the discrepancies of treatment these species receive from different taxonomists in Forzza et al. (2010). It was never the intention comprehensively list all species 
cultivated in Brazil. Moreover, for the purpose of the statistics presented in this paper, all analyses apart from the initial overview section were based only on the numbers of native plants. However, data from Forzza et al. (2010) may take into account some non-native species, influencing the comparisons performed within this article.

The term endemic, meaning that a taxon is unique to a defined geographic location, has been used at different levels (endemic to Brazil, endemic to one of Brazil's Biomes, a state or a vegetation type). The words endemic and restricted, or with restricted distribution, were used to analyse taxa in relation to where they occur, for instance, Parodia buiningii (Buxb.) N.P.Taylor (Cactaceae) is restricted to the state of Rio Grande do Sul and to the Pampa in Brazil, but it also occurs in Argentina, therefore it is not endemic of Brazil.

As one of the objectives of this work was to examine the effect of the continued input by specialists into the on-line Brazilian List system (Lista de Espécies da Flora do Brasil 2015), comparative gross percentage calculations highlighting growth and decrease in species number were calculated. These were based on the species number difference between 2015 and 2010 divided by the totals found in 2010 . These are presented alongside the total percentages in the results tables.

The term Biome used in the project and in the results and discussion of this paper are equivalent to the six Phytogeographic Domains, or Domínios Fitogeográficos defined by IBGE (2004).

\section{Results}

Overall

More than 110,000 names were included in the system by 2015 , while the original database in 2010 had 94,144 names (Tab. 1). All 69 names of Gymnosperms, as well as the further six names added by 2015 , were checked (Tab. 1 ). The positive balance of new Angiosperm names included in the system in five years was 9,274 (11.6\% of the initial total). The number of checked names, 85,400 , grew in balance by 20,033 , or $30.6 \%$ of the initial total of 65,369 in 2010 , thus today the Brazilian list has over $95.5 \%$ of its Angiosperm names checked by specialists (Tab. 1). Wherever possible, the checked names either marked as accepted names or as synonyms linked to an accepted name (Tab. 2). The present number of unplaced names of Angiosperms is 633, and a single name for Gymnosperms (Tab. 2).

At present, seed plant diversity totals 32,109 accepted native species (23 of which are Gymnosperms) belonging to 2,746 genera and 229 families (Tab. 2). With the addition of 921 native species between 2010 and 2015, the species number figure grew $3 \%$ in the last five years (Tab. 3). Overall endemism figures have grown proportionally more than the number of accepted native species, from 17,632 in 2010 (56.5\%) to $18,423(57.4 \%)$ in 2015 , with the addition of 791 endemic species, a gross increase of $4.5 \%$ (Tab. 3). The Brazilian Red List (Martinelli \& Moraes 2013) includes 1,974 species (1,772 endemic and 202 not endemic to Brazil) that were currently listed under one of these threat categories: critically endangered - CR, endangered - EN, and vulnerable - VU (Tab. 4).

\section{Top 10 families}

The top 10 families Fabaceae, Orchidaceae, Asteraceae, Rubiaceae, Melastomataceae, Bromeliaceae, Poaceae, Myrtaceae, Euphorbiaceae and Malvaceae contribute 15,404 to the total number of Angiosperm species (47.2\%). The total species contribution of these families appears to be more significant in terms of endemism, contributing 9,593 endemic species, or $62.3 \%$ of the endemism at the country level (Tab. 5). The increase found for the total species number $(4.3 \%)$ is lower than the endemism difference of $6.8 \%$ found for the top 10 families.

Nine of the ten largest families coincide with those found in the Catalogue (Forzza et al. 2010), the exception being Apocynaceae (down 5 species from 2010 - now with 754 species, of which 403 are endemic), that was surpassed by Malvaceae in 2015 (Tab. 5). Apart from Poaceae, where there was a decrease of 120 species, the general increase found was between 2.1\% (Rubiaceae) and 21.5\% (Euphorbiaceae) for the largest families. The remaining 214 families that occur in Brazil have between one and 756 species.

In terms of endemism, the gross increase was between 1\%(Orchidaceae) and 26.6\% (Euphorbiaceae), but in general endemism grew between 2.2\% (Asteraceae) and 8.7\% (Poaceae), with Myrtaceae (12.7\%) and Bromeliaceae (14\%) reaching slightly higher values.

\section{Top 30 genera}

The 30 largest genera of Brazilian Angiosperms add up to 6,380 species, representing $19.5 \%$ of the total diversity of the group. The contribution of these genera appears to be proportionally more significant in terms of endemism, contributing with 4,485 endemic species, or $24.3 \%$ of total endemism (Tab. 6).

The order in which the top 30 largest genera appeared in Forzza et al. (2010) has changed 


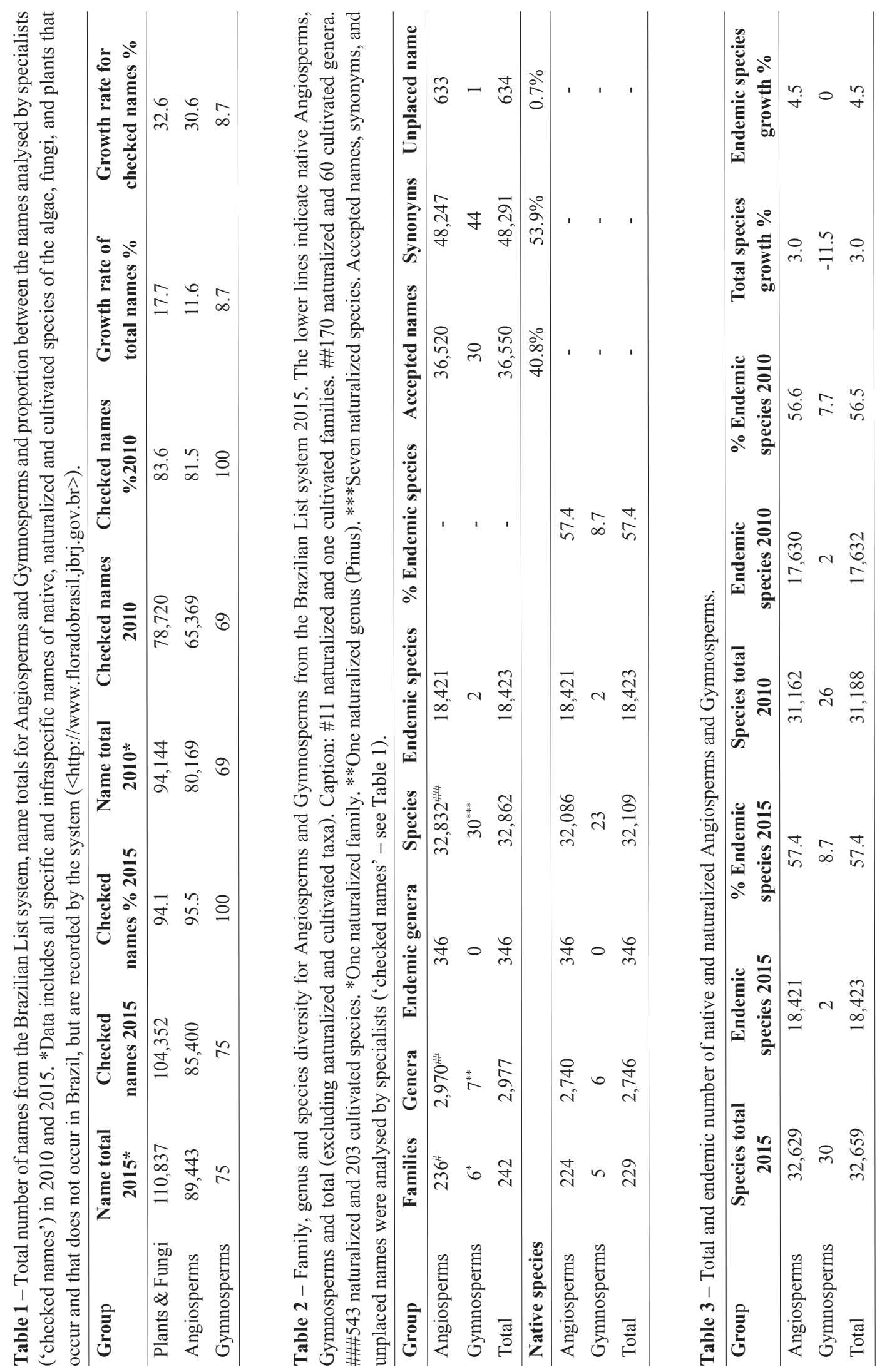



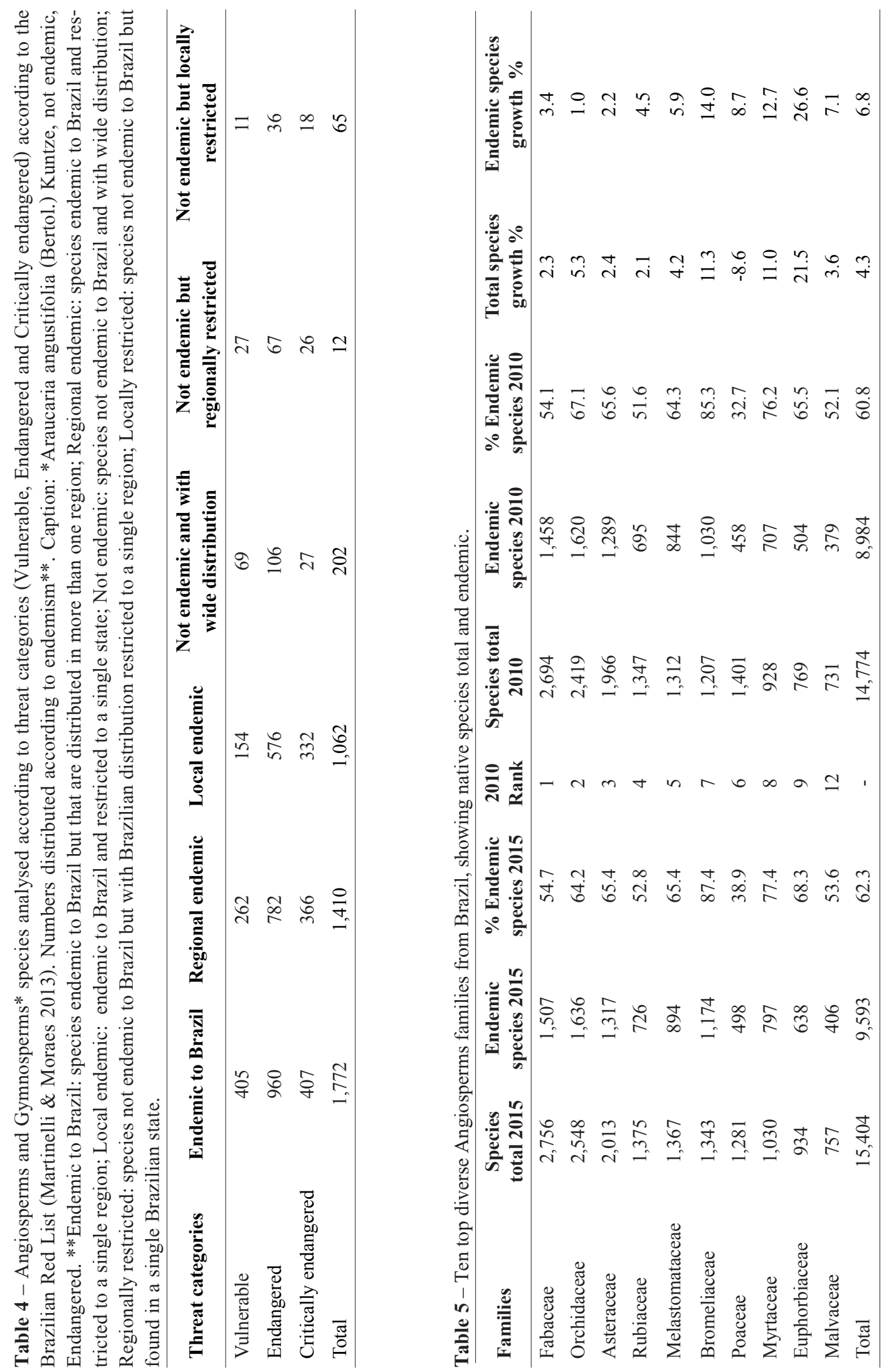
noticeably, with Eugenia overtaking Paepalanthus and Mimosa, and Paepalanthus falling to the third position, Croton climbing from $16^{\text {th }}$ to $4^{\text {th }}$ position, Psychotria falling from $6^{\text {th }}$ to $10^{\text {th }}$ position, Leandra from $10^{\text {th }}$ to $14^{\text {th }}$, Vriesea moving from $15^{\text {th }}$ to $11^{\text {th }}$ and Baccharis from $24^{\text {th }}$ to $17^{\text {th }}$ position. Dyckia, Pavonia and Anthurium reached the top 30 largest genera, while Inga, Justicia and, more dramatically, Hyptis, were overtaken.

While Croton was the genus with the largest increase in number of species, from 186 to 316 species (Tab. 6), other three amongst the most speciose genera have increased by around $20 \%$ or more: Baccharis (from 149 to 178 species), Dyckia (from 115 to 141 species) and Myrcia (from 215 to 260 species). The genera that were adjusted downwards are Paepalanthus (from 357 to 338 species), Psychotria (264 to 252) and Leandra (213 to 206).

The proportion of endemic species within these genera followed, in general, the increases or decreases in species number. However, Croton had a more dramatic endemism increase $(86.7 \%)$ compared to species richness growth of $69.9 \%$ and, in Rhynchospora, endemism increased by $45.5 \%$ for a species growth of $8.1 \%$. In relative terms, the percentage of endemic species of Rhynchospora moved from $24.3 \%$ of the species to $32.6 \%$.

Amongst the exceptions to this trend, Philodendron species increased 7.7\% from 156 to 168 species, while the endemism figure was adjusted from 127 to only 79 species, falling $37.8 \%$, from $81.4 \%$ to $47 \%$ endemic (Tab. 6). Despite the fact that the species numbers increased for Baccharis, the proportion of endemism has slightly decreased $(-2.91 \%)$. The genus Piper, with a slight increase in the number of species, had a gross endemic species decrease of $6.3 \%$. While the ten most diverse families presented a slight increase in the level of endemism when compared to the list produced in 2010 (Tab. 5 ), the 30 largest genera practically maintained their proportional contribution in percentages: $70.2 \%$ in 2010 and $70.3 \%$ in 2015 (Tab. 6).

\section{Biomes}

Seed plant occurrence in the Brazilian biomes is illustrated in Figure 3. While for the Gymnosperms (Tab. 7) the Amazon Rainforest is the Brazilian biome with the highest number of species, for Angiosperms (Tab. 8, Fig. 1) the highest species number is found in the Atlantic Rainforest, with 15,001 native species of which 7,432 (49.5\%), are endemic to this biome, followed by the Cerrado,
12,097 total species with 4,252 (35.1\%) endemic; Amazon Rainforest (11,896 total species, with $1,900(16 \%)$ endemic); Caatinga $(4,657$ total species, with 913 (19.7\%) endemic); Pampa (1,685 total species, with 102 (6.1\%) endemic); and Pantanal (1,277 total species, with 54 (4.2\%) endemic species).

The increment of species between 2010 and 2015 was proportionally higher for the two biomes with least species (Fig. 1, Tab. 8), totalling $44.3 \%$ (392 species) for the Pantanal and 25.3\% (340 species) for the Pampa. The Caatinga had an increase of $7.8 \%$ (337 species), which was a similar increase to the Atlantic Rainforest ( $7.4 \%$ or 1,029 species). The Cerrado gained an additional 712 species $(6.3 \%$ increase), and the Amazon Rainforest, with 547 species added since 2010, had the smallest increase (4.8\%).

The figures for endemism per biome followed the growth trend for the Pantanal (8 more endemic species, or $17.4 \%$ increase), Pampa (26 more endemic species, $34.2 \%$ increase), and Caatinga (169 more endemic species, $22.7 \%$ increase). Meanwhile the Atlantic Rainforest and the Cerrado had moderate growth of endemism numbers, with respectively 418 and 102 , an equivalent of a $6 \%$ and $2.5 \%$ increase. The Amazon Rainforest's recorded endemism decreased, with 48 less endemic species than it had in 2010 , a decrease of $2.5 \%$. In relative terms, from 2015, the endemism in the Amazon region represents $16.1 \%$ of the total species (Tab. 8).

Each biome was analysed according to its top ten Angiosperm families (Tab. 9) and, of the overall top ten families (see item

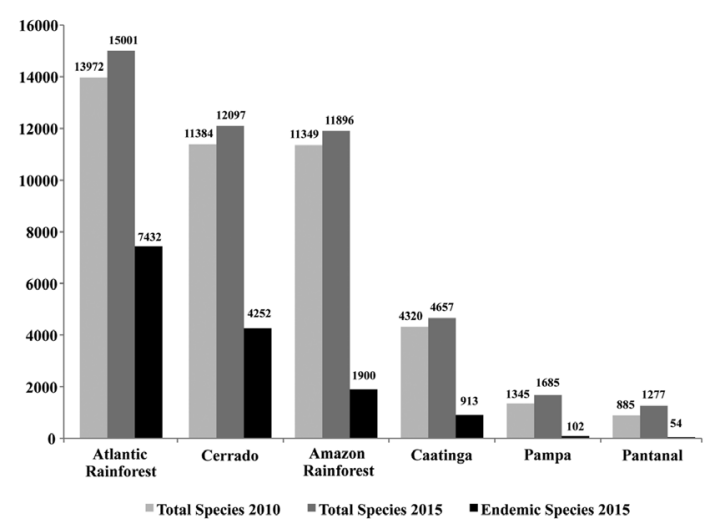

Figure 1 - Angiosperm species number per biome, with total numbers of species in 2010 and 2015, and endemic species in 2015. 


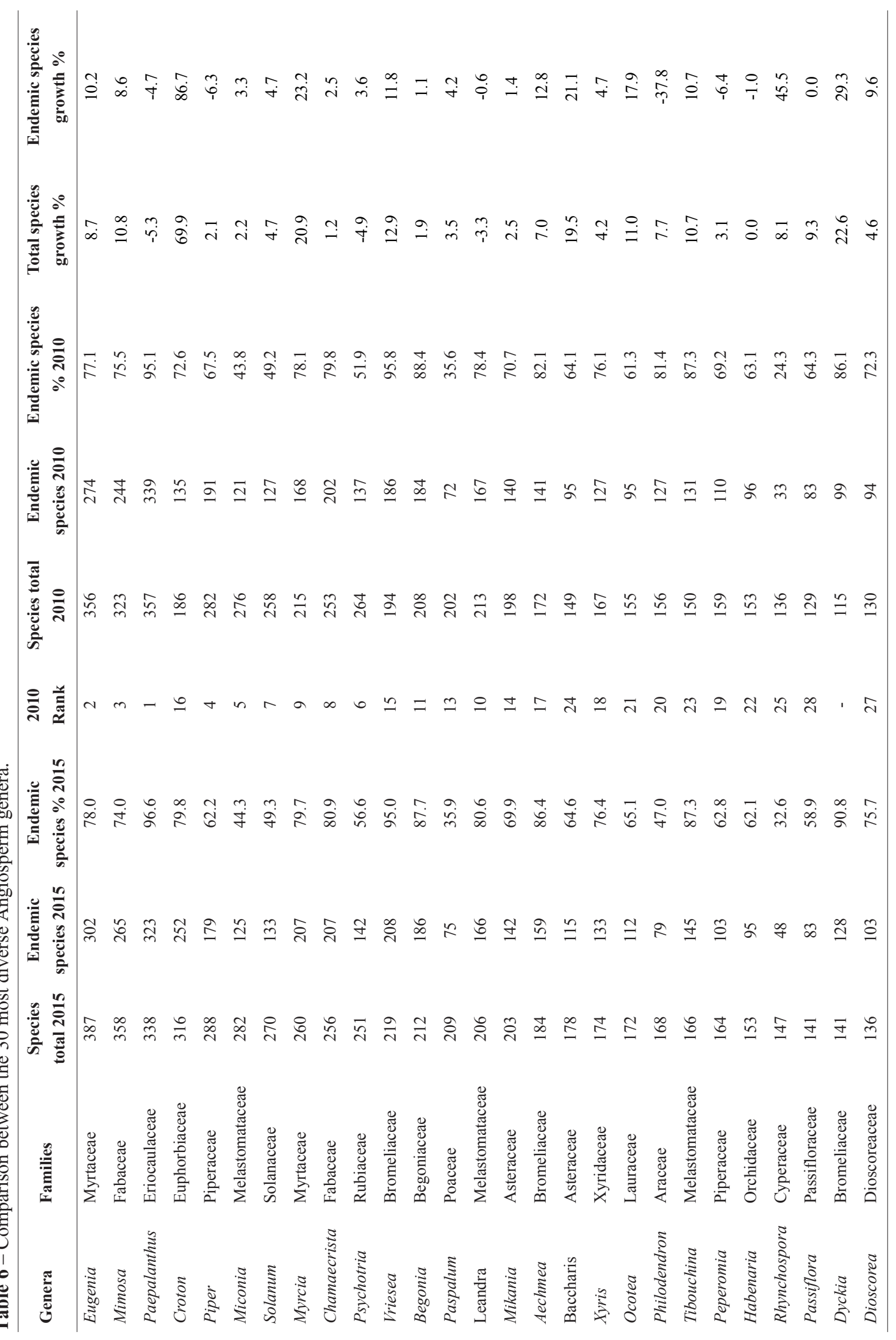



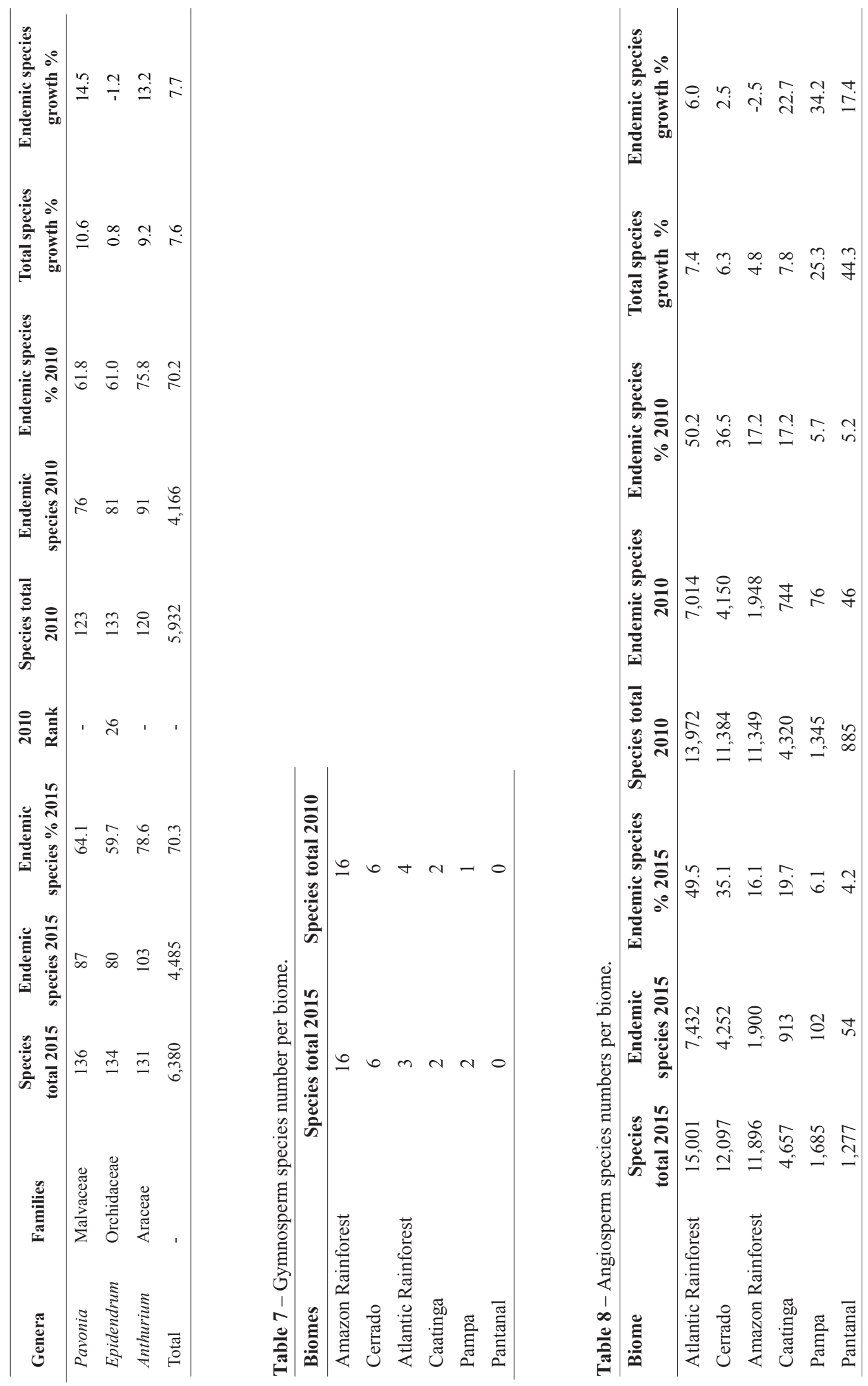


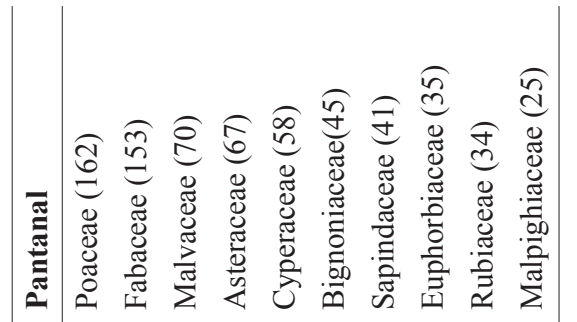

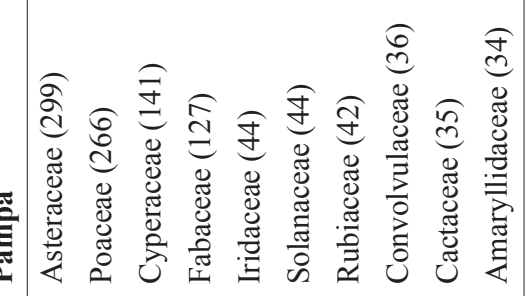

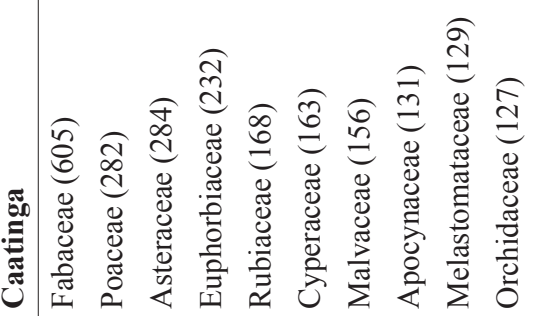

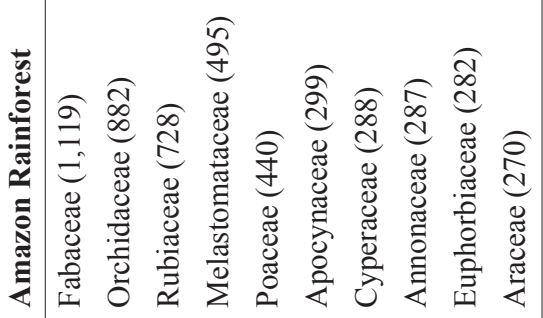

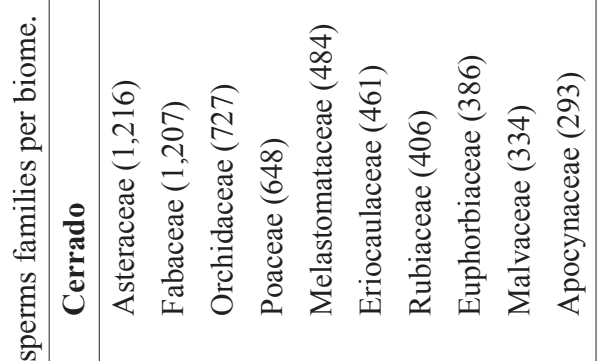

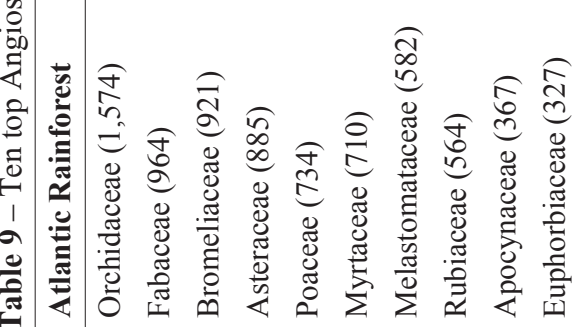
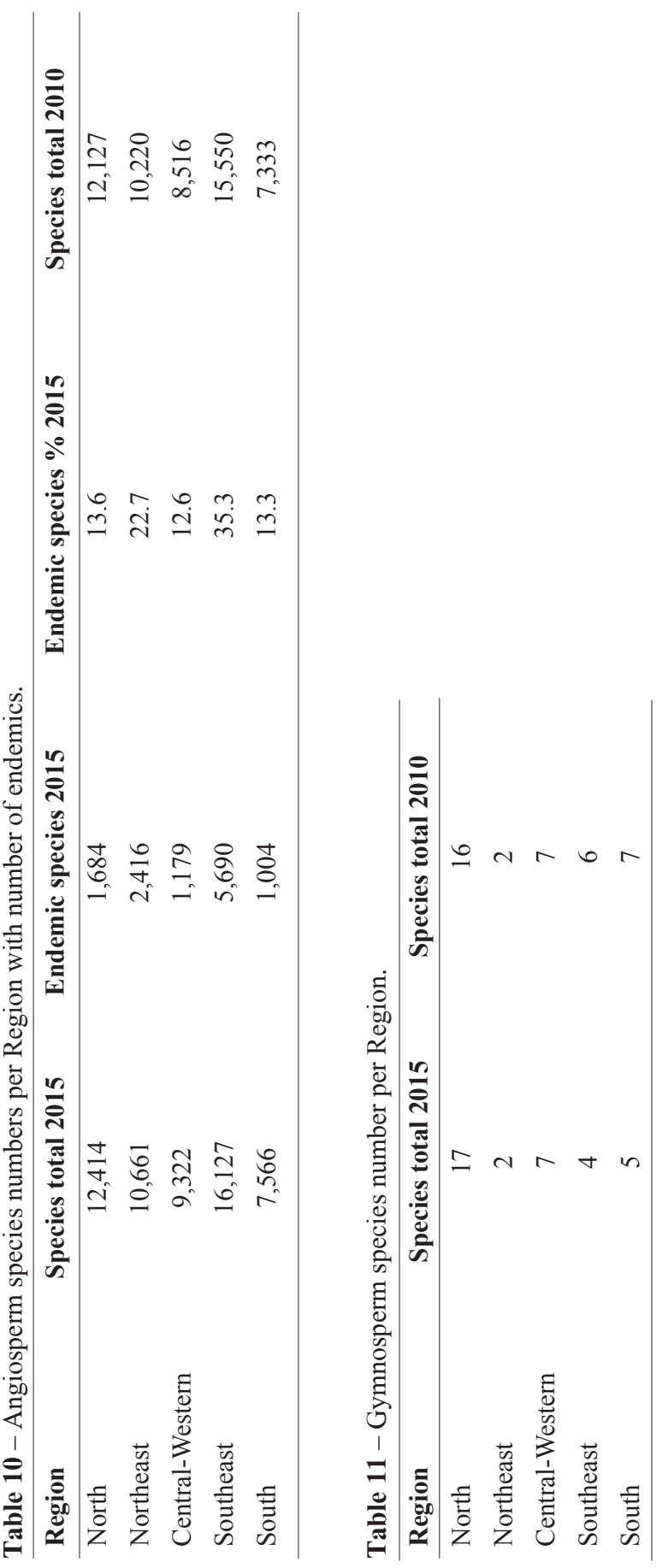
above), only Fabaceae, Poaceae and Rubiaceae appear among the top ten throughout all six biomes. Asteraceae and Euphorbiaceae appear in five biomes, while Apocynaceae, Cyperaceae, Melastomataceae and Orchidaceae appear in four. Malvaceae appears in three biomes. Thirteen plant families appear among the 10 top families under a single biome: Amaryllidaceae, Annonaceae, Araceae, Bignoniaceae, Bromeliaceae, Cactaceae, Convolvulaceae, Eriocaulaceae, Iridaceae, Malpighiaceae, Myrtaceae, Sapindaceae and Solanaceae.

Fabaceae is the most species rich family in the Amazon Rainforest and in the Caatinga, while it occupies the second position in the Atlantic Rainforest, Cerrado and Pantanal, and the fourth in the Pampa (Tab. 9). Poaceae, also included among the overall ten most diverse families, is the first in the Pantanal, and the second in the Caatinga and in the Pampa. Rubiaceae occupies the fourth position in the overall ten top families, but does not reach the five first positions in four biomes, however it is the third richest family in the Amazon Rainforest and the fifth in the Caatinga. Asteraceae, amongst the top ten families in five biomes apart from the Amazon, is the most important family in both Cerrado and Pampa. Euphorbiaceae occupies a noticeable position in the Caatinga, while it has a lower rank in the Atlantic Rainforest, Amazon Rainforest and Pantanal. Amongst the families present in four biomes, Orchidaceae figures as the most important family in the Atlantic Rainforest, while it appears in second place in the Amazon Rainforest, in third in the Cerrado and in tenth place in the Caatinga. Cyperaceae is the third most important one in the Pampa, while Malvaceae is the third most important one in the Pantanal. Among the families that appear in a single biome, Bromeliaceae is the most noticeable one as the third most important family in the Atlantic Rainforest. Pampa and Pantanal have families among their top 10 that are not in the list of the most diverse ones in other biomes (Tab. 9), with five exclusive for the Pampa (Iridaceae, Solanaceae, Convolvulaceae, Cactaceae and Amaryllidaceae) and three in the Pantanal (Bignoniaceae, Sapindaceae and Malpighiaceae).

\section{Brazilian Geopolitical divisions - Regions and States}

Regarding geopolitical subdivisions there was an increase in the number of Angiosperm species recorded for the Southeastern region that continues to be the most diverse $(16,127$ vs. 15,550 species in 2010), being the one with highest number of endemic species $(5,690)$, representing $35.3 \%$ of endemism (Tab. 10). On the other hand, the South has the smallest number of species (7,566 vs. 7,333 in 2010) and the lowest endemism as well (1,004 species, $13.3 \%$ endemism). In relation to Gymnosperms (Tab. 11), the North is the most diverse (17 species) and the Northeast the least diverse (two species). For Southeast and South regions there was a decrease of two species in 2015 in relation to 2010 (Tab. 11). Amazonas is the state with the highest number of species for Gymnosperms (12 species), followed for other two states that have part or all their territory included in the Amazonian biome (Tab. 12): Acre (8 species), Rondônia (7), Mato Grosso (6) and Pará (6). Six states (Amapá, Maranhão, Paraíba, Piauí, Rio Grande do Norte, and Tocantins) have no Gymnosperm records so far (Tab. 12).

The seven Brazilian states with the largest number of Angiosperm species remained in the same order found in 2010 (Tab. 13), with increased number of species varying from $8 \%$ to nearly $17 \%$, as follows: Bahia $(1,284$ species $-16.7 \%)$, Minas Gerais ( 849 species - 8.2\%), Amazonas (733 species - 9.7\%), São Paulo (604 species - 8.7\%), Rio de Janeiro (586 species - 8.7\%), Pará (652 species - 11.6\%) and Paraná (629 species - 12\%).

Below the seven states with the largest number of species, different addition rate of new records has caused inversions in states position in relation to what was found in 2010. Mato Grosso overtook Goiás, Espírito Santo surpassed Santa Catarina, Rio Grande do Sul overtook Acre, Rondônia passed Pernambuco, Roraima passed Maranhão and Tocantins overtook Piauí. The same trend of dramatic species number increase found within the biomes with the least species was true of the states with least number of species, such as Sergipe, that more than doubled its species count from 770 to 1,608 (103.8\% increase), while Rio Grande do Norte (72.8\%), Tocantins (70.3\%) and Alagoas (63.3\%) increased their numbers by more than $50 \%$.

In terms of Brazilian states (Tab. 13), there is a trend of sharp drop in endemism for Rio de Janeiro (less 105 endemic species, or $-8.9 \%$ than in 2010), Acre (less 50 species, or $-46.3 \%$ ), São Paulo (25 less species, -7.6\%), Goiás (24 less species, -4.6\%), Mato Grosso (15 less species, 
$-5.7 \%$ ), Maranhão (10 less species, -20.8\%), Amazonas (9 less species, -1.3\%), Pará (8 less species, -2.8\%), Pernambuco (7 less species, $-9.2 \%$ ), Rondônia (6 less species, $-12.8 \%$ ) and others states with 5 or less species. There was an increase in the number of endemic species registered for Espírito Santo, with 92 more endemic species, showing an increase of $19.5 \%$, Rio Grande do Sul (41 species, 23.2\%), Mato Grosso do Sul (14 species, 23.7\%) and Roraima (5 species, $17.2 \%$ ).

Table 12 - Gymnosperm species number per Brazilian State and Federal District.

\begin{tabular}{|c|c|c|}
\hline $\begin{array}{l}\text { States and Federal } \\
\text { District }\end{array}$ & $\begin{array}{c}\text { Species } \\
\text { number } \\
2015\end{array}$ & $\begin{array}{c}\text { Species } \\
\text { number } \\
2010\end{array}$ \\
\hline Amazonas & 12 & 12 \\
\hline Acre & 8 & 8 \\
\hline Rondônia & 7 & 4 \\
\hline Mato Grosso & 6 & 5 \\
\hline Pará & 6 & 4 \\
\hline Paraná & 4 & 6 \\
\hline Minas Gerais & 4 & 4 \\
\hline Goiás & 4 & 5 \\
\hline Rio Grande do Sul & 4 & 7 \\
\hline São Paulo & 3 & 6 \\
\hline Santa Catarina & 3 & 6 \\
\hline Rio de Janeiro & 3 & 5 \\
\hline Roraima & 3 & 0 \\
\hline Bahia & 2 & 2 \\
\hline Distrito Federal & 2 & 3 \\
\hline Espírito Santo & 2 & 3 \\
\hline Alagoas & 1 & 1 \\
\hline Ceará & 1 & 0 \\
\hline Mato Grosso do Sul & 1 & 1 \\
\hline Pernambuco & 1 & 1 \\
\hline Sergipe & 1 & 1 \\
\hline Amapá & 0 & 1 \\
\hline Maranhão & 0 & 0 \\
\hline Paraíba & 0 & 0 \\
\hline Piauí & 0 & 0 \\
\hline Rio Grande do Norte & 0 & 0 \\
\hline Tocantins & 0 & 0 \\
\hline
\end{tabular}

\section{Life-forms}

The proportion of life-forms varies within the different biomes, with trees appearing in larger proportion in the Amazon and Atlantic Rainforests, while herbs predominate in the Pampa (Tab. 14, Fig. 2). Other biomes, such as the Pantanal, Cerrado, Caatinga and, partly, the Atlantic Rainforest also have strong presence of herbs, but this is less extreme than what was found for the Pampa. Lianas are more expressive in the Amazon and Atlantic Rainforests, followed by the Pantanal. When comparing the profiles of the different biomes (Fig. 2), the Atlantic Rainforest and the Cerrado appear to be most comparable, also resembling what was found for the Caatinga, with a balanced presence of shrubs and trees, and $30 \%$ or more of herbs, with moderate numbers of lianas.

The proportion found between tree and shrub versus herbaceous species, including lianas, varies amongst the biomes (Tab. 14). The lowest proportion was recorded for the Amazon Rainforest, where for each tree species there are two shrubs or herbs, i.e. a ration of $1: 2$; while the Atlantic Rainforest presents 1:4 proportion. For the Caatinga, it was found to be $1: 6$, the Cerrado has 1:7 and the Pantanal, 1:8. The grassland dominated Pampa has a proportion of $1: 31$, i.e. one tree species for over 30 species of shrub, subshrub, herb or liana.

\section{Substrate}

The majority of plant species throughout Brazilian biomes are terrestrial (Fig. 4), ranging from $83.7 \%$ in the Amazon Rainforest through to 75.6 in the Atlantic Rainforest (Tab. 15).

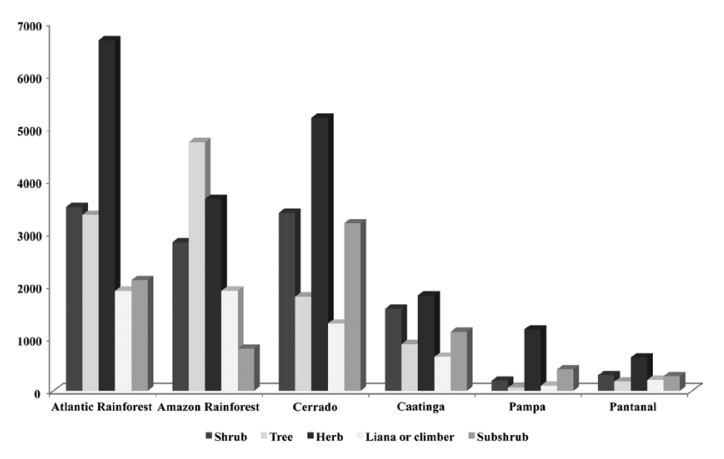

Figure 2 - Angiosperm life-form species number per biome. The exact values are found in table 14 . 
Table 13 - Angiosperm species number per Brazilian State and Federal District.

\begin{tabular}{|c|c|c|c|c|c|c|c|c|}
\hline $\begin{array}{l}\text { States and Federal } \\
\text { District }\end{array}$ & $\begin{array}{c}\text { Species } \\
\text { number } \\
2015\end{array}$ & $\begin{array}{c}\text { Endemic } \\
\text { species } \\
2015\end{array}$ & $\begin{array}{c}\text { Endemic } \\
\text { species } \\
\% 2015\end{array}$ & $\begin{array}{c}\text { Species } \\
\text { number } \\
2010\end{array}$ & $\begin{array}{c}\text { Endemic } \\
\text { species } \\
2010\end{array}$ & $\begin{array}{c}\text { Endemic } \\
\text { species \% } \\
2010\end{array}$ & $\begin{array}{c}\text { Total } \\
\text { species } \\
\text { growth } \\
\%\end{array}$ & $\begin{array}{c}\text { Endemic } \\
\text { species } \\
\text { growth \% }\end{array}$ \\
\hline Minas Gerais & 11,239 & 2,245 & 20.0 & 10,039 & 2,158 & 20.8 & 8.2 & 4.0 \\
\hline Bahia & 8,970 & 1,694 & 18.9 & 7,686 & 1,621 & 21.1 & 16.7 & 4.5 \\
\hline Amazonas & 8,261 & 683 & 8.3 & 7,528 & 692 & 9.2 & 9.7 & -1.3 \\
\hline São Paulo & 7,525 & 329 & 4.4 & 6,921 & 354 & 5.1 & 8.7 & -7.1 \\
\hline Rio de Janeiro & 7,354 & 1,076 & 14.6 & 6,768 & 1,181 & 17.4 & 8.7 & -8.9 \\
\hline Pará & 6,278 & 282 & 4.5 & 5,626 & 290 & 5.2 & 11.6 & -2.8 \\
\hline Paraná & 5,891 & 192 & 3.3 & 5,262 & 188 & 3.6 & 12.0 & 2.1 \\
\hline Mato Grosso & 5,729 & 247 & 4.3 & 4,585 & 262 & 5.7 & 25.0 & -5.7 \\
\hline Goiás & 5,625 & 496 & 8.8 & 4,818 & 520 & 10.8 & 16.7 & -4.6 \\
\hline Espírito Santo & 5,304 & 564 & 10.6 & 3,971 & 472 & 11.9 & 33.6 & 19.5 \\
\hline Santa Catarina & 4,753 & 182 & 3.8 & 4,112 & 183 & 4.5 & 15.6 & -0.5 \\
\hline Rio Grande do Sul & 4,238 & 218 & 5.1 & 3,673 & 177 & 4.8 & 15.4 & 23.2 \\
\hline Acre & 4,028 & 58 & 1.4 & 3,740 & 108 & 2.9 & 7.7 & -46.3 \\
\hline Mato Grosso do Sul & 3,657 & 73 & 2.0 & 2,816 & 59 & 2.1 & 29.9 & 23.7 \\
\hline Rondônia & 3,290 & 41 & 1.2 & 2,544 & 47 & 1.8 & 29.3 & -12.8 \\
\hline Distrito Federal & 3,223 & 33 & 1.0 & 2,672 & 36 & 1.3 & 20.6 & -8.3 \\
\hline Pernambuco & 3,133 & 69 & 2.2 & 2,421 & 76 & 3.1 & 29.4 & -9.2 \\
\hline Roraima & 3,075 & 34 & 1.1 & 2,239 & 29 & 1.3 & 37.3 & 17.2 \\
\hline Maranhão & 2,855 & 38 & 1,3 & 2,414 & 48 & 2.0 & 18.3 & -20.8 \\
\hline Amapá & 2,655 & 34 & 1.3 & 2,198 & 37 & 1.7 & 20.8 & -8.1 \\
\hline Ceará & 2,427 & 47 & 1.9 & 1,888 & 49 & 2.6 & 28.5 & -4.1 \\
\hline Tocantins & 2,306 & 45 & 2.0 & 1,354 & 48 & 3.5 & 70.3 & -6.3 \\
\hline Piauí & 1,992 & 30 & 1.5 & 1,416 & 33 & 2.3 & 40.7 & -9.1 \\
\hline Paraíba & 1,837 & 10 & 0.5 & 1,272 & 9 & 0.7 & 44.4 & 11.1 \\
\hline Alagoas & 1,800 & 11 & 0.6 & 1,102 & 10 & 0.9 & 63.3 & 10.0 \\
\hline Sergipe & 1,569 & 3 & 0.2 & 770 & 2 & 0.3 & 103.8 & 50.0 \\
\hline Rio Grande do Norte & 1,222 & 4 & 0.3 & 707 & 3 & 0.4 & 72.8 & 33.3 \\
\hline
\end{tabular}

The Pantanal has the largest proportion of plants inhabiting aquatic substrates $(14.2 \%)$, followed by Pampa (7.3\%), Caatinga (4.5\%), Amazon Rainforest (3.1\%), Cerrado (3.0) and Atlantic Rainforest (2.4\%). Caatinga (10.3\%), Cerrado (9\%) and Pampa $(8.5 \%)$ have a high representativity of rupicolous plant species (Tab. 15). The Atlantic Rainforest is the biome with the highest number of epiphytic species, with $12.2 \%$, followed by the Amazon Rainforest (7\%). If taking into account epiphytes plus hemiepiphytes, the number is even higher for the Atlantic Rainforest (13\%), followed by the Amazon Rainforest (9\%), Cerrado (3.7\%), Caatinga (3\%), Pampa (0.9\%), and Pantanal $(0.8 \%)$. Parasitic plants, despite the fact that the Amazon Rainforest (133 species), Cerrado (125) and Atlantic Rainforest (122) present the highest values of hemiparasites (Tab. 15), the largest proportional representation is found in the Pantanal (1.6\%), followed by the Caatinga (1.3\%). Saprophytes are present in the Amazon Rainforest $(0.3 \%)$, Atlantic Rainforest $(0.2 \%)$ and Cerrado $(0.1 \%)$, but were not recorded so far for Caatinga, Pampa and Pantanal (Tab. 15). 


\section{Vegetation types}

Within the 24 vegetation types recognized by the Brazilian List (Lista do Brasil 2015), including Anthropized areas (Tab. 16), the highest Angiosperm number of species is found in Ombrophilous forest (12,000 species). Analysing only the species total, this is followed by 'Cerrado lato sensu' (7,210 species), 'Terra firme forest' $(5,722)$ and 'Campo rupestre' $(4,928)$, Gallery Forest $(4,259$ species $)$ and Semideciduous Seasonal Forest (3,384 species). Grassland reaches almost 3,000 species while

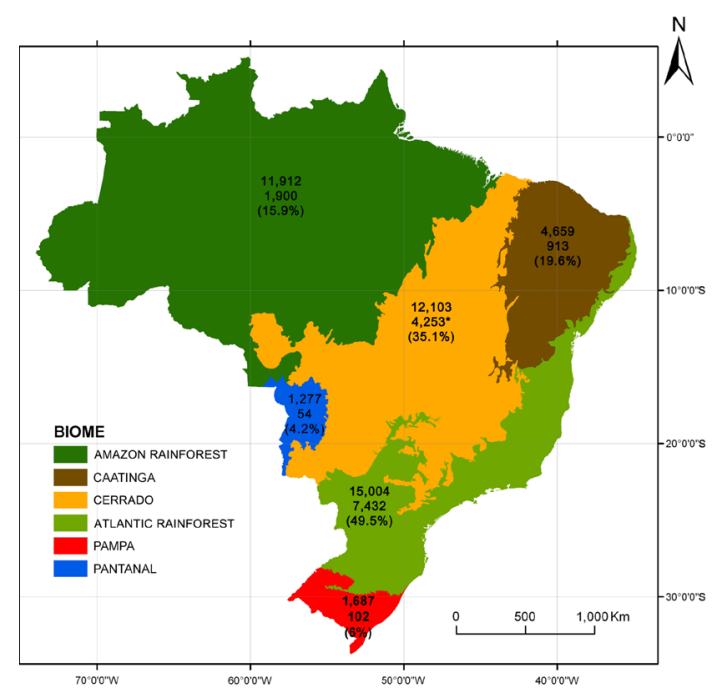

Figure 3 - Map of Brazilian biomes showing the total number of seed plant species (top number), the number of endemic species (middle number), and the percentage endemism for each biome. *Podocarpus barretoi Laubenf. \& Silba is the only endemic species of Gymnosperm.

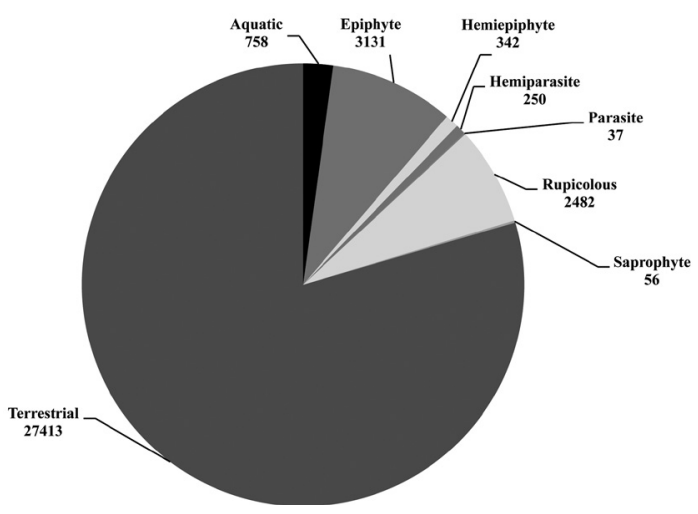

Figure 4 - Substrate types in the Angiosperms.
'Restinga', Altitude Grassland and 'Caatinga stricto sensu', as well as the Anthropized areas, have around 2,000 species records each. All other vegetation types were scored for less than 1,900 species, and the smallest number of species was found in the Mangrove (81 species) (Tab. 16).

Species restricted to a single vegetation type show a slightly different pattern from that found for total species richness (Tab. 16), with Ombrophilous forest $(5,210)$, 'Terra firme forest' $(2,014)$, 'Campo rupestre' $(1,994)$, 'Cerrado lato sensu' $(1,799)$ and Grassland (638) topping the list. Lower richness of endemic species was found in comparison to restricted species, also with differences in relation to their distribution in different vegetation types. The largest number of endemic species per vegetation type was, again, recorded for Ombrophilous forest $(4,159)$, followed by 'Campo rupestre' $(1,951)$, 'Cerrado lato sensu' $(1,357)$, 'Terra firme forest' (598) and Altitude grassland (479). Mangrove had no endemic species, while Palm grove had only six endemic out of 240 species (Tab. 16).

When analysing the relative endemism, the 'Campo rupestre' has the highest percentage of endemism (1,951 endemic out of 4,928 species, $39.6 \%$ ), followed by the Ombrophilous Forest (34.7\%), Altitude grassland (21.8\%) and 'Cerrado lato sensu' (18.8\%). Aquatic vegetation has shown the highest percentage of restricted species $(45.1 \%)$ but much lower endemism, as was also reported for the 'Terra firme forest' $(35.2 \%)$. Vegetation types where the number of restricted species is similar to the number of endemics were 'Carrasco', 'Campo rupestre', 'Caatinga stricto sensu', Palm grove, Mixed ombrophilous forest, 'Restinga' and Semideciduous seasonal forest.

While the Angiosperms are present in all vegetation types (Tab. 16), the Gymnosperms occur only in seven of those (Tab. 17), predominantly in the 'Terra firme forest' (eight species), Gallery Forest (six) and Amazon savanna (four). The latter, together with the 'Terra firme forest' present the highest number of species restricted to these vegetation types, with four each (Tab. 17). 

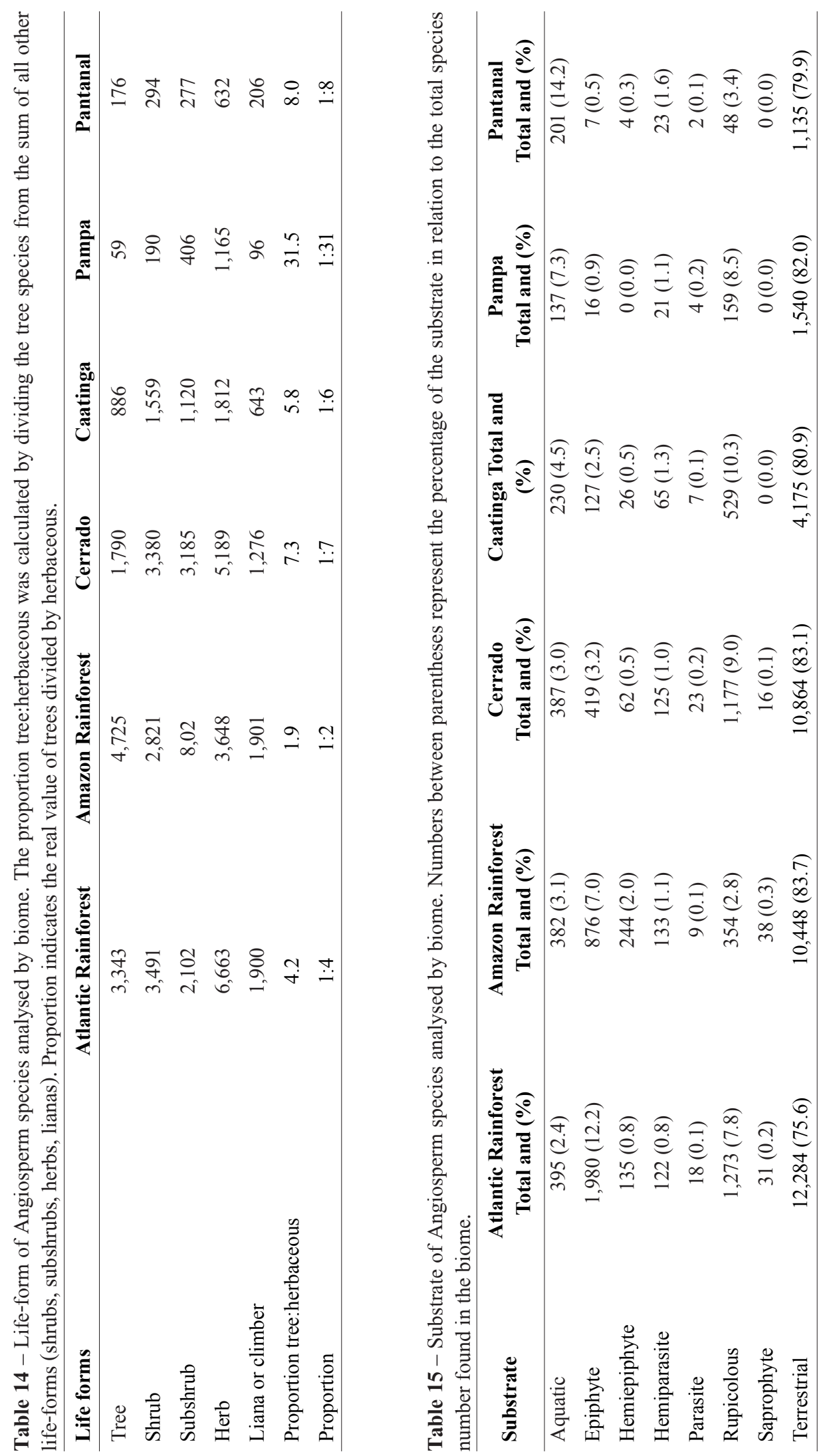


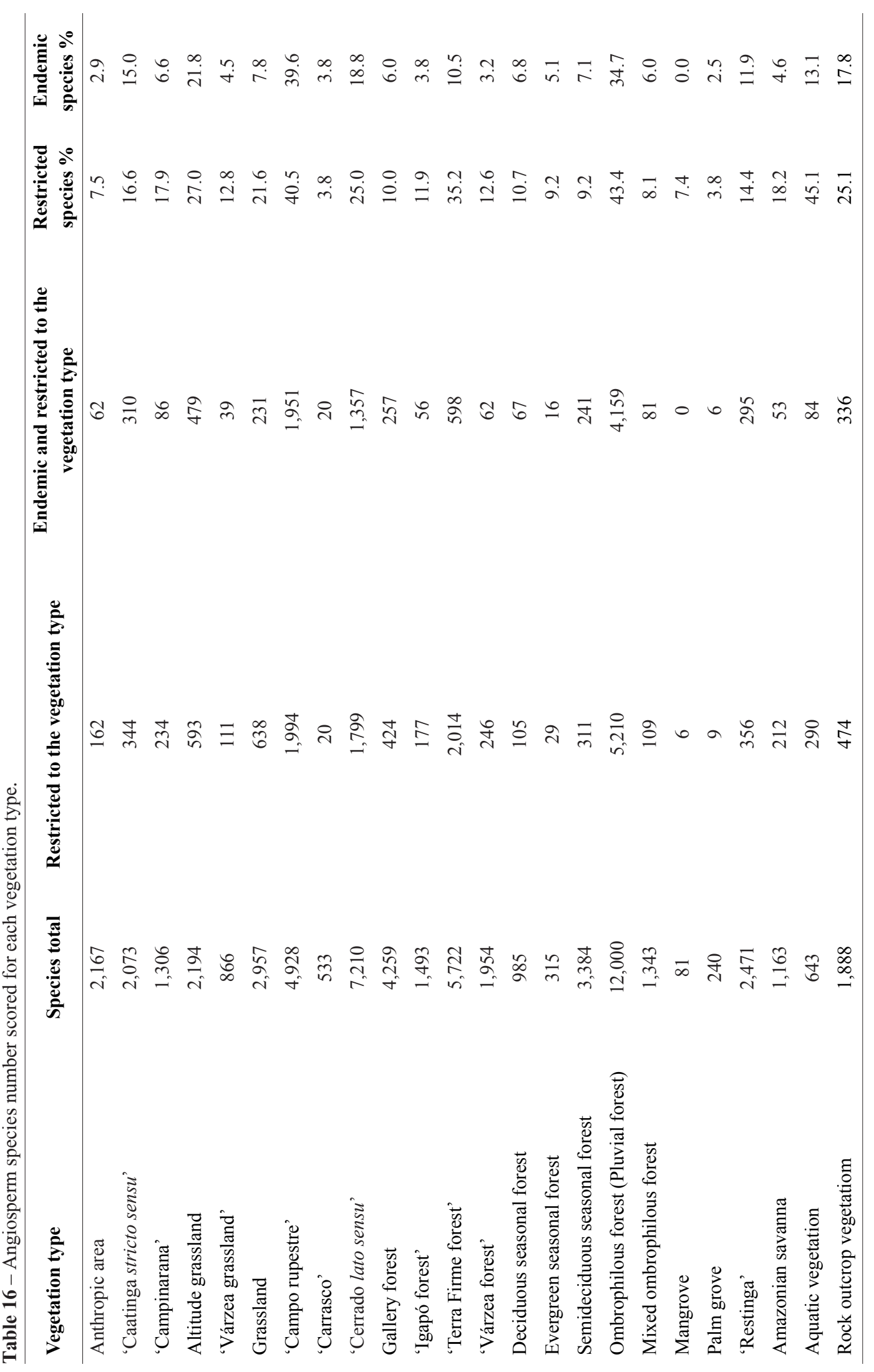




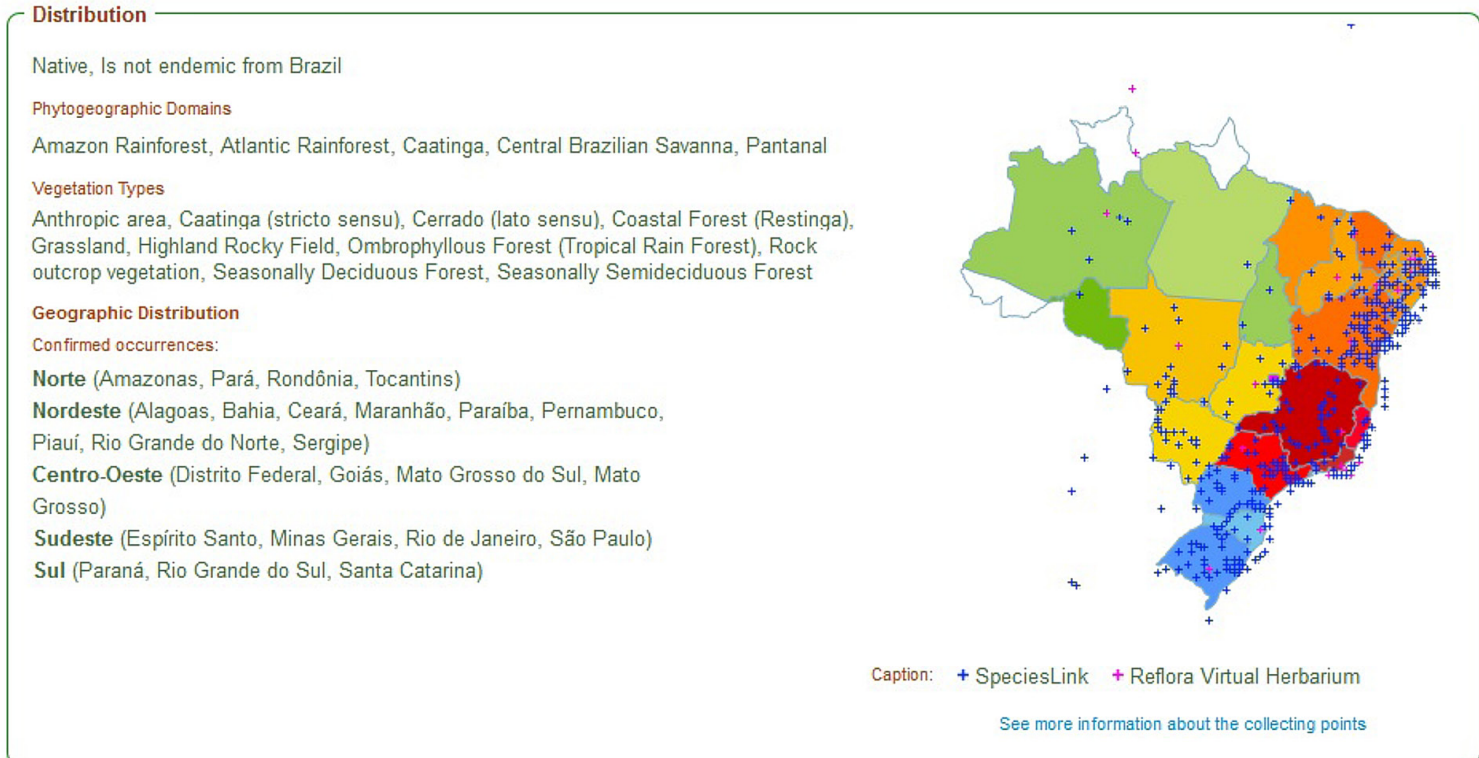

\section{Detailed Information of collecting points \\ commelina erecta}
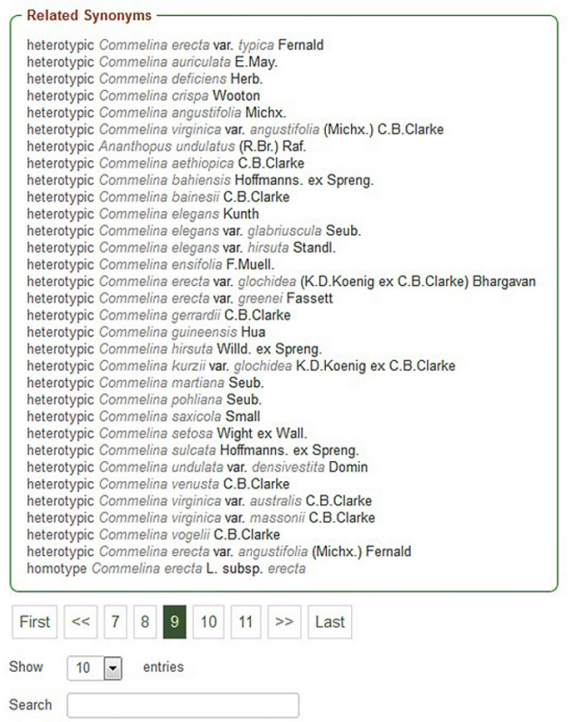

\begin{tabular}{|c|c|c|c|c|}
\hline & \multirow{2}{*}{\multicolumn{2}{|c|}{ Collector }} & \multirow[b]{2}{*}{ Determiner } \\
\hline Num. Cat. & Taxa & & & \\
\hline RB 00478160 & $\begin{array}{l}\text { Commelina } \\
\text { erecta }\end{array}$ & $\begin{array}{l}\text { Reflora Virtual } \\
\text { Herbarium }\end{array}$ & D. Gonçalves & M.O.O.Pelegrini \\
\hline RB00478168 & $\begin{array}{l}\text { Commelina } \\
\text { erecta }\end{array}$ & $\begin{array}{l}\text { Reflora Virtual } \\
\text { Herbarium }\end{array}$ & V.Perazzo Earbosa & J.A.Lira Neto \\
\hline RB00478171 & $\begin{array}{l}\text { Commelina } \\
\text { erecta }\end{array}$ & $\begin{array}{l}\text { Reflora Virtual } \\
\text { Herbarium }\end{array}$ & A.Q.Lobão & M.O.O.Pelegrini \\
\hline RB00478173 & $\begin{array}{l}\text { Commelina } \\
\text { erecta }\end{array}$ & $\begin{array}{l}\text { Reflora Virtual } \\
\text { Herbarium }\end{array}$ & V.Perazzo Barbosa & J.ALira Neto \\
\hline RB00478175 & $\begin{array}{l}\text { Commelina } \\
\text { erecta }\end{array}$ & $\begin{array}{l}\text { Reflora Virtual } \\
\text { Herbarium }\end{array}$ & A.Q.Lobão & M.O.O.Pelegrini \\
\hline
\end{tabular}

$\begin{array}{ll}\text { State } & \text { Municipality } \\ \text { RJ } & \text { Saquarema } \\ \text { PB } & \\ \text { RJ } & \text { Saquarema } \\ \text { PB } & \text { Areia } \\ \text { RJ } & \text { Saquarema }\end{array}$

\begin{tabular}{cll} 
Locality & \multicolumn{2}{c}{ Latitude Longitude } \\
Saquarema, Rio de Janeiro, Sudeste, Brasil, América do Sul & -22.8786 & -42.5185 \\
Remígio (Agreste). Paraíba, Nordeste, Brasil, América do Sul & -7.1205 & -36.8349 \\
.Saquarema, Rio de Janeiro, Sudeste, Brasil, América do Sul & -22.8786 & -42.5185 \\
Chã do Jardim. Areia, Paraíba, Nordeste, Brasil, América do Sul & -6.9475 & -35.6936 \\
.Saquarema, Rio de Janeiro, Sudeste, Brasil, América do Sul & -22.8786 & -42.5185
\end{tabular}

Figure 5 - Above: Distribution map provided to the contributors by the on-line system, showing herbarium records distributed throughout Brazil and neighbouring countries. Below: Table provided to the contributors by the on-line system, relating the crosses to the herbarium data and enabling them to see provenance and determiner of each specimen. 
Table 17 - Gymnosperm species number scored for each vegetation type.

\begin{tabular}{lcc}
\hline Vegetation type & Species total & Restricted to the vegetation type \\
\hline 'Campinarana' & 3 & 1 \\
Gallery forest & 6 & 3 \\
'Terra firme forest' & 8 & 4 \\
Ombrophilous forest (Pluvial forest) & 1 & 0 \\
Mixed ombrophilous forest & 1 & 0 \\
'Restinga' & 1 & 0 \\
Amazonian savanna & 4 & 4 \\
\hline
\end{tabular}

\section{Discussion}

\section{Overall}

The continued refinement of the Brazilian List over five years involved intensive review of the data already entered, with the addition of new records for Brazil, synonymization of names into already accepted names, updating names following new taxonomic framework, and specialist checking and accepting newly described species. Species number grew through checking and accepting newly described species and adding new records for Brazil.

While for the Gymnosperms all the included names were checked both in 2010 and 2015, Angiosperm names had around $82 \%$ of their names checked in 2010. A considerable number of names (both accepted and synonyms) were added to the system and checked by the specialists. The number of new Angiosperm names included in the system between 2010 and 2015 was 9,274 $(11.6 \%)$, growing less dramatically in relation to the total numbers, where $16,623(17.7 \%)$ were added, reflecting mostly the activity of the phycology and mycology specialist groups, for which the state of knowledge was always known to be less developed (Maia \& Carvalho Jr 2010; Bicudo \& Menezes 2010).

In relation to 2010 , the number of checked names of Angiosperms grew 30.6\%, addressing both the newly included names and the extant, but not yet checked, names from the 2010 edition that were then estimated at $18.5 \%$ (calculated from Table 1). The list is now in a much better situation, with almost $94 \%$ of its names checked and, wherever possible, either marked as accepted names or as synonyms linked to an accepted name.

As an indication, there were 1,191 new names of Angiosperms published for Brazil in the period between 2010 and 2014 (IPNI 2015). Not all these new taxa were added as accepted species to the list as some of them were considered synonyms by the specialists, but it is likely that a large part of them would have been added. According to Sobral \& Stehmann (2009), Brazilian new species represented an average of $7.8 \%$ of the plants described for the world between 1990 and 2006. In the years prior to this project (2004-2010), we found that the average percentage of Brazilian plants described compared to the rest of the world was around $8.5 \%$, while from 2010 this figure appears bigger, at $12.2 \%$. An acceleration in the number of species described for Brazil during the period of the project can also be noticed, as from 2004 to 2009 the average species described for Brazil per year was $178.3+/-36$ while from 2010 to 2014 the figure increased to $252.6+/-32.1$.

New records for Brazil were spotted through the collection, study and naming of new material, much of which was promptly digitalized by herbaria and made available on-line through the portal of the Brazilian List. New records were also highlighted by catalogues, such as Zuloaga et al. (2008) and Jørgensen et al. (2014), floras and monographs (i.e. Medeiros et al. 2014).

Included in the present figures is also the decrease of species numbers resulting from synonymization and changes of circumscription of accepted species, and exclusion of species that were cited for but not effectively located within the national territory thus far.

Better knowledge is becoming available regarding increase in species range beyond the Brazilian borders and prior errors originated by the default setting as 'endemic' during the successive revisions of the Brazilian List were corrected. Even taking these readjustments into account, we saw an overall steady increase both for accepted species 
totals (3\%) and endemic species $(4.5 \%$, or $4.1 \%$ if we eliminate 62 indications for Anthropized area from Table 16) between 2010 and 2015.

The number of threatened plant species currently found in the Brazilian Red List (Tab. 4) is slightly above $6 \%$ the total number of species of seed plant accepted for Brazil. When considering only Brazilian endemic species, the number of threatened plants represents $9.6 \%$ of the species. According to Brummitt et al. (2015), the expected number of species endangered worldwide represents around $20-26 \%$. For specialist groups that were globally assessed, such as Cactaceae (Zappi et al. 2012), almost $32 \%$ of the species belong to one of the three categories of threat. The smaller proportion currently recorded for Brazil as a whole reflects the fact that the red-listing process in Brazil did not depart from a complete list of taxa, but focused in former lists of endangered species suggested by botanists. In order to get to a realistic picture of how endangered the Brazilian flora really is, a blanket approach studying family by family, species by species is urgently needed.

\section{Top 10 families}

This suite of families represents $47.2 \%$ of the species richness of Angiosperms in Brazil, having been increased by $68.5 \%$ (630 out of the 921 species) in relation to the number of species recorded in 2010 (Forzza et al. 2010). In terms of endemism, the increase was more expressive, at $77 \%$, or 609 of the total of 791 endemic species newly recorded for Angiosperms between 2010 and 2015 belonging to the top 10 families.

The Apocynaceae, formerly the tenth largest family (Forzza et al. 2010), was the only family to be surpassed in species richness by the Malvaceae, number 10 in 2015. Apart from the Poaceae, which has decreased in size by 120 species $(-8.6 \%)$, the increase in species numbers was between 1 and $26.6 \%$ for the largest families, with Rubiaceae $(2.1 \%)$, Fabaceae $(2.3 \%)$ and Asteraceae $(2.4 \%)$ showing the slowest increase while Euphorbiaceae $(21.5 \%)$ has been the fastest growing family between 2010 and 2015, with a difference well above the 3\% found for the Angiosperms as a whole. Two other families that have also markedly increased in size during this period were the Bromeliaceae (11.3\%) and the Myrtaceae (11\%).

Sobral \& Stehmann (2009) pointed out Bromeliaceae as one of the five fastest growing families together with the Orchidaceae,
Fabaceae, Asteraceae and Poaceae. By 2015, while Bromeliaceae continues to grow at a high rate, increase in new species in other families has slowed down, with Orchidaceae at medium pace, Fabaceae and Asteraceae presenting slow increase, and the Poaceae decreased in size through the elimination of over 200 cultivated and introduced species from the present calculations. The increase in the growth speed of the species richness in Euphorbiaceae and Myrtaceae reflects a possible change in the balance of the activities of researchers describing biodiversity in Brazil during the last few years. It is possible that, for less 'popular' and more complex, speciose plant families such as these ones, this acceleration may be a direct result of the present project.

In terms of endemism, the three families where the endemism figures grew faster are Euphorbiaceae (26.6\%), Bromeliaceae (14\%) and Myrtaceae (12.7\%), all well above the growth found for Angiosperms as a whole (4.5\%). On the other hand, Orchidaceae has only 16 more endemic species than five years ago, increasing its percentage of endemism by only $1 \%$, while Asteraceae had a modest increase of $2.2 \%$.

\section{0 largest genera}

Amongst the 30 top genera, 19 belong to the 10 top families, thus influencing the numbers exposed above. The largest species increase took place in Croton, where the increase of the number of endemic species was also the highest. Following the creation of an international group to study this mega-genus in 2001 (Berry 2015), around 15 new species of Croton were described between 2010 and 2015, and more new discoveries are being published. However, the 130 species difference cannot be explained by the discovery and description of new species, and it stems from a delay in including existing information (checking all accepted names) that some groups faced during the implementation of the Brazilian List online. This is the most high profile example of instances that occurred in other, smaller groups, and by no means the rule within this mainly successful project.

In most cases where there was a significant decrease in species numbers within a genus, the adjustment could be tracked back to a new generic circumscription; for example several species formerly included in Hyptis were transferred to five recently recognized genera (Cantinoa, Cyanocephalus, Eplingiella, Medusantha, Mesosphaerum, and Oocephalus; see Pastore et al. 2011; Harley \& Pastore 2012). 
Endemism reduction that was linked to a decrease of species number was seen in Paepalanthus (-16 species) and Leandra (-one species). Adjustments regarding endemism that were not always linked to a reduction in species number were seen in Philodendron (-48 species), Piper (-12 species), Peperomia (-seven species) and Epidendrum (-one species). The more extreme case, that of Philodendron, can be explained by indepth research in the Amazonian species, with the study of additional specimens of species previously thought to be endemic to Brazil collected in bordering countries, such as Colombia, combined with the fact that the initial default setting of the Brazilian List was marked 'ON' for endemism. Readjustments made within Philodendron show that the endemic species of the genus are, in their majority, from the Atlantic Rainforest. The revision process during the last five years was supported by growing evidence from collections of a vast number of herbaria that went on-line during this period, thus enabling the botanists to visualize species dot maps and perform important corrections for the endemism in their groups (Fig. 5).

The top 10 families have shown a slightly higher proportional growth in endemism than the 30 largest genera that remained collectively similar in terms of their endemism between 2010 and 2015. It is possible that the numbers for the group of 30 top genera were influenced by the dramatic drop in endemism caused by further studies in Paepalanthus, Piper and Philodendron.

\section{Biomes}

The overall trend of growing species numbers was maintained, to a certain extent, in data concerning the Brazilian biomes. The almost exclusively Brazilian Atlantic Rainforest and the Cerrado continue to lead in terms of biodiversity and endemism amongst seed plants (Fig. 3), coinciding with the hotspots highlighted by Mittermeier et al. (1998, 2004) and Myers et al. (2000). They are followed by the Amazon Rainforest and the Caatinga; and the Cerrado, a biome currently under severe threat of rapid destruction due to the expansion of the agricultural frontier, has now a wider gap in relation with the Amazon Rainforest through increased species and endemism records added during the last five years.

While the number of species now recorded for the Atlantic Rainforest has increased 7.4\% $(1,029$ species $)$ over the number presented by
Forzza et al. (2010), the records of endemic species has been less expressive, with only 418 extra endemic species, or $6 \%$, added to this biome between 2010 and 2015, causing a fall in endemism percentage from $50.2 \%$ (Forzza et al. 2010) to $49.5 \%$. For the Cerrado, the increase in species number was smaller, at $6.3 \%$ (713 species), while the endemism increase was also proportionally smaller, at $2.5 \%$, with 102 endemic species record added to this biome, also a fall in the percentage of endemic species from $36.5 \%$ (Forzza et al. 2010) to $35.1 \%$. It is possible that this rise in species numbers, yet not followed closely by the increase of endemic species, results from refinement of the knowledge of plant distributions within and beyond each biome, for instance the presence of Atlantic Rainforest species in other biomes by the way of gallery forests in the Cerrado or of enclaves of humid highland forest in the Caatinga, or by species being recorded beyond the Brazilian borders within the same biome (for instance in the Bolivian Cerrado or in the extension of the Atlantic Rainforest into Paraguay and Argentina).

Meanwhile the Caatinga, the only exclusive Brazilian biome, saw an increase of $7.8 \%$ (337 species) with 169 records of endemic species added, or an increase of $22.7 \%$ from the 2010 data, bringing the percentage of endemic species from $17.2 \%$ (Forzza et al. 2010) to $19.7 \%$. This is the only biome where the percentage of endemic species has risen during the 2010-2015 period and this is connected to the local botanical activity in the universities, and may also be related to the compilation of lists and floras that include the Caatinga biome (i.e. Siqueira Filho 2012; Prata et al. 2013).

Both Pampa and Pantanal, with respectively 340 species $(25.3 \%)$ and 392 species (44.3\%) added, have seen dramatic increases in the biodiversity recorded. In the Pantanal this may be a reflection of recent efforts employed to produce an up-to-date checklist for Mato Grosso do Sul (Farinaccio et al. 2015 no prelo). However, even if the addition of eight endemic species to the 2015 list meant an increase of $17.4 \%$, the overall percentage of endemic species in this biome has decreased from $5.2 \%$ to $4.3 \%$, no doubt because a great many species from the Pantanal are also found in Argentina, Bolivia and Paraguay (Sarmiento 1983, Haase \& Beck 1989, Larrea-Alcázar et al. 2010). The recent surveys that inform the Bolivian Catalogue (Jørgensen et al. 2014) probably 
contributed with additional evidence of new examples of such taxa. In the Pampa, the addition of 26 endemic species (34.2\%) did not change the overall percentage of endemic species, that remains almost unchanged, at $5.7 \%$. It is possible that the increase in species number for the Pampa is a consequence of comparisons with the Catalogue of the 'Cono Sur' (Zuloaga et al. 2008) and the concentration of local effort to catalogue the Flora of Rio Grande do Sul.

In the case of the Amazon Rainforest, the increase of $4.8 \%$ (547 species) was the smallest increase in terms of species total. Moreover, the percentage of endemic species for this biome has decreased by $48(-2.5 \%)$ species from 1,948 in 2010 (Forzza et al. 2010) to 1,900 in 2015, with an overall endemic percentage drop from $17.2 \%$ to $16.1 \%$. Considering the large expanse covered by this biome, it is surprising that it now falls behind the Cerrado in terms of species richness, but, in terms of species endemism, this result is justified. The Cerrado has more diverse and abundant vegetation types than the Amazon Rainforest, however, and includes large sections spanning over much wider altitudinal and latitudinal ranges. On the other hand, the fact that the Cerrado is more accessible and better studied, thus better represented in herbaria, may play some role in the recording of known species number.

Apart from the survey work developed for the whole state of Acre by Daly \& Silveira (2009), research in the Amazon Rainforest has focused on isolated locations. Survey work such as the Flora of the Reserva Ducke, by Ribeiro et al. (1999), looking at all life-forms rather than focussing on woody species, has shown that systematic and complete collections may add large quantities of known and not yet described species to each locality studied within this biome. Comparing the two studies cited above, the proportions between woody and herbaceous life-forms are different. According data from Daly \& Silveira (2009), the proportion between trees and other life-forms found for all vegetation types in Acre was 1:2; while the data from Ribeiro et al. (1999) indicated a proportion of 1:1 between trees and herbaceous plants for an area of "Terra Firme" forest.

The research carried out on the Amazon basin by ter Steege et al. (2013) suggests that there are possibly between 15-16 thousand tree species. Moreover, from our findings we now understand that there are 2 or more shrubby or herbaceous species for each Amazonian tree species. Considering these proportions, Hopkins (2003) projection that the Brazilian Amazon Rainforest might harbour between 40 and 50 thousand species of seed plants, many of them yet undescribed, seems to be more appropriate for the whole basin. Hopkins (2007) and ter Steege et al. (2013), point at the poor state of floristic knowledge of the Amazon basin. In addition, botanical research in the Amazon Rainforest has been biased towards studying its tree flora, but there is much else to be discovered besides this if more inclusive surveys of all life-forms were to be carried out. Analysing the number of 0,18 exsiccate per $\mathrm{km}^{2}$ (including duplicates) in the Northern region (Specieslink 2015) the need of intensive and systematic work in this area to cover the gaps of knowledge about its biodiversity becomes evident.

When analysing the different biomes according to their more abundant families in terms of species, it was found that their shared ten top families were only Fabaceae, Poaceae and Rubiaceae, all extremely species rich and not exclusively woody (in fact, Poaceae can be considered marginally woody when bamboos are taken into account). Asteraceae and Euphorbiaceae appear in five biomes, while Melastomataceae and Orchidaceae appear in four, together with Apocynaceae and Cyperaceae, which are not amongst the overall top ten families. Malvaceae appears in three biomes. Families that appear amongst the top ten within a single biome are seldom amongst the overall top ten (Bromeliaceae, Myrtaceae), more often making a single apparition (Amaryllidaceae, Annonaceae, Araceae, Bignoniaceae, Cactaceae, Convolvulaceae, Eriocaulaceae, Iridaceae, Malpighiaceae, Sapindaceae and Solanaceae). In the case of Myrtaceae and Bromeliaceae, both possessing a center of diversity in the Atlantic Rainforest, their sheer number of species is so large within that biome that it supports their presence within the top ten. The Eriocaulaceae is a point in case, with huge biodiversity within the Campos Rupestres that are included within the Cerrado biome, thus occupying the sixth position within this very rich biome, despite not being one of the overall top ten families. In biomes with less species, specific characteristics pertaining these individual families, or 'one offs', that may be favouring their presence amongst the top ten, are the woodiness of Annonaceae in the Amazon Rainforest, the climbing habit of Bignoniaceae, Malpighiaceae and 
Sapindaceae in the Pantanal and the corm and bulbbearing, herbaceous Iridaceae and Amaryllidaceae found to be expressive in the Pampa. Also in the Pampa, the expressivity of rupicolous plants may have led to the position occupied by the Cactaceae.

\section{Brazilian Geopolitical divisions -} Regions and States

While a balance of 921 new native seed plant records included for Brazil, the number of additional state records is much larger, in excess of 19 thousand new state records entered in the system during the last five years. The release of a facility that generates a provisional map by plotting the underlying herbarium collections made available to the specialists in 2011 has guided them towards including many records by observing the map and checking the specimen identification data. As some of these herbarium collections included specimens from outside Brazil, the map was also useful to double-check endemism of some taxa, encouraging further research and adjustments (Fig. 4).

States with floras and lists partially or totally published by 2010 have shown a smaller increase in the number of species than states where the floristic knowledge is still incomplete. The list of plants from the Catalogue of the Flora of Acre (Daly \& Silveira 2009) was one of the databases added to the system when it was created, and this was reflected in a modest increase of species for this state (7.7\%), while dramatic adjustments to the number of endemic species for the state were made between 2010 and 2015, with a fall in the number of endemic species of the order of $-46.3 \%$. The recent growth of knowledge regarding the flora of Acre is described by Medeiros et al. (2014). Also in the process of organizing its Catalogue, the state of Rio de Janeiro (Baumgratz et al. 2014) saw moderate growth in the species number (586 species, growth of $8.7 \%$ ) and a fall on the number of endemic species (105 species, decreasing -8.9\%). On the other hand, states such as Paraná, whose list was recently published (Kaehler et al. 2014), using Forzza et al. (2010) as its starting point, saw an increase of 629 species, with $12 \%$ growth in the species number and a slight increase in the number of endemic species. Another ongoing project that may probably be contributing to an accelerated increase of the species count is the checklist of Espírito Santo (Dutra et al. in press), focussing on this still poorly known and extremely biodiverse state where 1,333 new species records, or a percentual growth of $33.6 \%$, took place during the last five years. It is possible that an intensification of work within the state of Espírito Santo has resulted in range extension of many species formerly thought to be endemic to Rio de Janeiro, resulting in the decrease of endemism seen for the latter state.

Through the publication of the Catalogue (Forzza et al. 2010), the states of the Northeastern region of Brazil were stimulated to record their flora at an intense pace, with increases of more than $28 \%$ on the species numbers for all states (Sergipe $103.8 \%$, Rio Grande do Norte 72.8\%, Alagoas 63.3\%, Paraíba 44.4\%, Piauí 40.7\%, Pernambuco $29.4 \%$ and Ceará $28.5 \%$ ), with exception of Bahia, the second most species rich state, which saw a respectable increase of 1,284 species (16.7\%), and Maranhão with an increase of 441 species (18.3\%). Finally, the state with the highest growth percentage in terms of species numbers was Sergipe, probably due to the publication of its own Flora project (Prata et al. 2013).

Some Amazonian states show that, despite the publication of the list, the knowledge seems to have stalled and did not improve much during the 2010 to 2015 period, namely in the Amazonas, with less than $10 \%$ increase, and Pará, with $11.6 \%$.

The state of Tocantins is a relatively recent split of a former larger state of Goiás and many of the species historically referred to Goiás have wider distribution, occurring also in Tocantins. The growth of the number of species from this state has reached an increase of $70.3 \%$, occupying the third place in growth, after Sergipe and Rio Grande do Norte. The mapping facility has made this situation more obvious and hence there was a drop in the number of endemic species from Goiás $(-4.6 \%)$ due to their newly recorded occurrence in Tocantins.

\section{Life-forms}

When comparing the proportion of tree species with the other life-forms, such as shrubs, herbs and lianas, there is wide variation among the Brazilian biomes. Five of the biomes (Atlantic Rainforest, Cerrado, Caatinga, Pampa and Pantanal) show a majority of herbs amongst their life-forms, while tree species are more expressive in the Amazon Rainforest, but even so in a proportion of 1:2. Even in biomes composed mostly by forested vegetation, such as the Amazon and the Atlantic Rainforests, different proportions have been found, with the Atlantic Rainforest showing a proportion of 1:4. This diversity of life-forms in 
the Atlantic Rainforest biome is justified by the presence of many different vegetation types in this biome, including 'Restinga', Rock outcrops, Ombrophilous, Semideciduous and Mixed forests, Altitude grassland and even outlying 'Campo rupestre'. The Atlantic Rainforest is also a centre of diversity for Bromeliaceae and Orchidaceae, both herbaceous families with expressive numbers of epiphytes.

Amongst biomes where the vegetation is mostly composed by different savanna types, the Caatinga has a proportion of 1:6, and the Cerrado has 1:7. At the other end of the spectrum from the Amazon Rainforest, open habitats such as the Pampa and Pantanal count with less tree species, being rated at respectively 1:31 and 1:9. The Pampa is the only biome characterized by large extensions of grassland, and the diversity of tree species is very reduced under its subtropical conditions. While the lianas are less well represented in the Atlantic Rainforest, Cerrado and Caatinga, subshrub species are very few in the Amazon Rainforest, and trees, as already mentioned, are the least represented life-form in the Pampa and the Pantanal. Such proportions represent a useful snapshot of the overall different types of biomes in Brazil: forests, savannas and grasslands.

The presence of some exclusive families amongst the top ten families in the different biomes provides, in some cases, a link with this information. The abundance of species of Malpighiaceae, Sapindaceae and Bignoniaceae in the Pantanal may be linked to the presence of habitats suitable for climbers, even if the biome possesses low diversity of tree species. The high position in the top ten rank for herbaceous families such as Iridaceae and Amaryllidaceae in the Pampa is linked to the grassland habitats, together with the expressive numbers of species of Poaceae, Cyperaceae and Asteraceae. The presence of Fabaceae and Rubiaceae amongst the top 10 families in all six biomes help to understand the landscape diversity found within the Brazilian biomes, as they are families with huge amplitude in terms of life-forms, from small herbs to tall trees.

\section{Substrate}

While terrestrial plants represent constantly more than three quarters of the biodiversity in terms of substrate in all biomes, epiphytes were the second major component of the Atlantic Rainforest biome. The first and third position amongst the top ten families in the Atlantic Rainforest was occupied by Orchids and Bromeliads, both well represented in terms of epiphytic species. Other speciose group of epiphytes is Peperomia (Piperaceae), the $22^{\text {nd }}$ largest genus in Brazil. The Araceae, with almost $50 \%$ of the species occurring as epiphytes or hemiepiphytes, are prominent in the Atlantic Rainforest and also appear amongst the top ten families within the Amazon Rainforest biome. Despite their comparative low diversity in relation to the Atlantic Rainforest, epiphytism was also the second substrate occupied by plants in the Amazon Rainforest.

While aquatic plants were, as expected, expressive in the Pantanal and Pampa, it could have been expected that they would occupy a larger proportion of the vegetation types available in the Amazon (Igapó and Várzea forests, Várzea fields, Aquatic Vegetation), however this was not conveniently highlighted by our data. However, in terms of proportion within the Amazon Rainforest biome, the aquatic plants occupy the third, following terrestrial and epiphytic substrate. The Caatinga, despite of its xeric conditions, was the third biome to display an expressive aquatic vegetation, due to the seasonal floods that create temporary lagoons teeming with life during the rainy season.

The high number of rupicolous species found in the Cerrado and Caatinga biomes can be justified by the presence of the 'Campo rupestre' vegetation type across both. This substrate is the second most relevant in the Pampa, where many low rock outcrops are found almost at the same level as the grass. Upon land conversion for agriculture or into pasture, these outcrops are quickly deteriorated and lose their originally restricted flora.

In the Atlantic Rainforest the rupicolous substrate is the third most relevant following terrestrial and epiphytic, and this can be explained by the Altitude grassland (Martinelli 2007) as well as the Rock outcrop vegetation type, a term used for non-crystalline outcrops generally at lower altitude that do not fall within the definition of 'Campo rupestre'. These Rock outcrops, or inselbergs, are also abundant within the Caatinga and the Cerrado. The ecotone between Campo rupestre and Caatinga stricto sensu, known as Carrasco, is also stony and harbours rupicolous species. Parasites and saprophytes are proportionally less expressive in the Brazilian flora, and occur basically in the Amazon Rainforest, Atlantic Rainforest, and Cerrado. 
Vegetation types

The inclusion of the 24 vegetation types represented a huge advance in terms of the refinement of the knowledge Brazilian plant diversity, and it was not without difficulties. Similarly to what we experienced at the start of the project in 2009, contributors engaged differently with the input of this new request for information. These concepts were clearer for the botanists that are active in the field and have experience of collecting in different environments, however, due to the diversity of professionals involved in the project there were some obvious shortcomings in the data.

An example of this was seen for Anthropised areas that were considered as an independent "vegetation type" in the list. These areas, however, can be originated from any of the 23 vegetation types that were submitted to drastic human actions, such as deforestation, degradation, urbanization, mining, etc. There were 162 native species listed as restricted to disturbed environments, of which 62 are supposedly endemic to Brazil.

Other problems arose from the initial difficulty faced by the committee to reach an agreement for the vegetation types list. Ideally, those should be comparable from one biome to another, but in reality we settled for a list that recognizes a considerable number of local formations as unique. One good example is 'Terra firme' forest, basically an Ombrophilous forest type from the Amazon basin, and Deciduous seasonal forest, a forest type that might be included by some in 'Caatinga stricto sensu'. Likewise, it is possible that confusion generated between 'Campo rupestre' and Rock outcrop vegetation. The analysis in those cases has to take into account that the conflicts may be handled differently and variable levels of consistency were achieved in the different groups.

Mirroring what was found for the Atlantic Rainforest biome, its most expressive vegetation type, the Ombrophilous forest, has not only the highest number of species but a large percentage of species restricted to this type of forest in Brazil, and a large proportion of endemic species to this vegetation type. The Atlantic Rainforest is not totally endemic to Brazil, with outlying areas in Argentina and Paraguay, which account for the difference between the restricted species and endemism to this vegetation type in Brazil.

Similarly, the 'Cerrado lato sensu' is the most extensive vegetation type of a largely Brazilian biome that extends into Bolivia and Paraguay, and also in the Venezuelan 'llanos' (Sarmiento 1983), thus the percentage of species restricted within Brazil is higher than the percentage of endemic Cerrado lato sensu species found in the country.

The "Terra firme" forest is undoubtedly the most species rich vegetation type of the Amazon Rainforest biome, however the percentage of both restricted and endemic species are lower than for the former two, a fact that is fully justified by the vast sections of Amazon Rainforest found in the lowland areas of neighbouring countries such as Peru, Colombia, Venezuela and the Guianas, with many species widely distributed through many of these and beyond.

The 'Campos rupestres', with their shared distribution in the Cerrado (Minas Gerais, Goiás, Tocantins) and Caatinga biomes (Bahia) occupy the fourth place in number of species, with $40.5 \%$ of the 4,928 being restricted to this vegetation type, with nearly all of those $(39.6 \%$ ) being also endemic to this vegetation type in Brazil. It is possible now to point to the fact that this extremely biodiverse vegetation type contributes towards the relatively high endemism percentages found at the biome level both for the Caatinga and Cerrado biomes. Recent data from the Serra do Cipó reveal that, within a single of mountain range, nearly three thousand vascular plants can be found (Pirani et al. 2015).

In comparison, the Altitude Grassland in the Atlantic Rainforest contributes with a small number of species, reflecting its restricted geographic spread, nonetheless with $21.8 \%$ of endemic species. In contrast, for the Aquatic vegetation, where the specialized life-forms and requirement of the species have led to the highest percentage of restricted species $(45.1 \%)$, the percentage of endemism is low because these species are widely distributed throughout Brazil and also into neighbouring countries.

\section{Concluding remarks}

The overall position of Brazil as the country harbouring the highest plant diversity (Forzza et al. 2012) continues to be accurate. Added to this, the endemism levels found in Brazilian seed plants continue to be outstanding, surpassed only by large island floras (such as Australia, Papua New Guinea, Madagascar), archipelagos (such as New Caledonia, New Zealand, French Polynesia) and South Africa $(65 \%)$, the only other continental country where levels of endemic flora surpass $50 \%$. 
There was marked improvement in the list as a realistic reference for species found in Brazil, apart from the somewhat disappointing slow growing records regarding the Amazon Rainforest biome, partly reflected both in the numbers shown for the biome, the Brazilian Northern region and some states that are included in it (Acre, Amapá, Amazonas, Pará, Roraima and Rondônia). On the other hand, the results obtained reinforce the important role of the Atlantic Rainforest and Cerrado on the diversity of Angiosperms in Brazil, and also of the Caatinga, as an exclusive Brazilian biome. Considering their smaller surface area, both Pampa and Pantanal contribute much towards the Brazilian plant diversity, even if they share many species with neighbouring countries.

When considering the richest vegetation types in terms of their overall, restricted and endemic species number, it is possible to see that the country displays a balance between the forests and the more open habitats. Amongst the six richest types, four are forests (Ombrophilous, 'Terra firme', Gallery and Semideciduous Seasonal forests) and two are open vegetation types ('Cerrado lato sensu' and 'Campo rupestre'). Amongst the restricted, two forests (Ombrophilous and 'Terra firme') and four open vegetation types ('Campo rupestre', 'Cerrado lato sensu', Grassland and Altitude grassland). When focusing on endemism, two are forests (Ombrophilous and 'Terra firme') while four are open habitats ('Campo rupestre', 'Cerrado lato sensu', Altitude grassland and Rock outcrops).

The elevated total number of native species recorded for Anthropized areas $(2,167)$ may still partly reflect different concepts used by contributors. The importance of this data, which includes a large number of possible pioneer plants with potential for reforestation and re-establishment of natural habitats cannot be underestimated (Elliott et al. 2013).

Extremely interesting data have been compiled during the second phase of this endeavour, enabling more refined analysis of biomes according to habit, substrate and vegetation types. While the Brazilian forested biomes, namely the Amazon and Atlantic Rainforests, have respectively 1:2 (one tree to two shrubby/herbaceous species) and 1:4 (one tree to four shrubby/herbaceous species), savannic biomes, such as Cerrado, Caatinga and Pantanal, have ratios of 1:6, 1:7 and 1:8. In the grass dominated Pampa, the ratio is 1:31. After the predominant terrestrial habit, the second highest group are the epiphytes, more expressive in the Atlantic Rainforest and pushing up the numbers of Orchidaceae and Bromeliaceae into the higher positions in terms of species rich families. Rupicolous plants are very expressive in the Caatinga, Cerrado and Pampa. Doubtlessly more interesting links can be found by further refining the data made available in this study.

Less well-known areas, such as the states of Tocantins, southern Maranhão, Piauí and northwestern Bahia, have shown increased volume of data. A large proportion of this biodiversity corresponds to the portions of these states covered by the Cerrado biome (2,130 of the 2,306 species found in Tocantins; 1,977 of the 2,855 species from Maranhão; 1,621 of the 1,992 from Piauí; and 1,977 of the 8,970 from Bahia). However, the future of the Cerrado natural resources is threatened by concerted efforts from the Brazilian government and national and international investors to further expand the arable land for soybean, cotton, sugarcane, and rice production (MaToPiBa 2015). The Cerrado in these states is already responsible for $10 \%$ of the country's grain production, however the recent growth of the knowledge regarding the plant species found in these states between 2010 and 2015, with Piauí's plant list growing by $40.7 \%$ and Tocantins by a staggering $70.3 \%$ suggests that such knowledge may still be far from complete.

During the last five years, the relatively slow increase of the knowledge regarding the species found in the Amazon Rainforest is concerning, especially when we take into account the rampant deforestation and habitat change (large scale agriculture including soybean and cattle farming, construction of hydroelectric dams with huge immediate and long term impact on the environment, large-scale mining), all this supported by government sectors that are increasingly averse to conservation and hostile towards Brazil's need to preserve its natural habitats through protected areas.

\section{Acknowledgements}

Ministry of Science and Technology - MCTI; Brazilian National Research Council - CNPq; The Alberto Luiz Coimbra Institute for Graduate Studies and Research in Engineering at the Federal University of Rio de Janeiro - COPPE/UFRJ; Information Technology Department of the Rio de Janeiro Botanical Gardens - TI JBRJ; to Alexandre Antonelli and two anonymous reviewers that contributed valuable comments to the manuscript; 
and to all the herbarium curators that work hard to make data and images available for consultation worldwide.

\section{References}

Baumgratz, J.F.A.; Coelho, M.A.N.; Peixoto, A.L.; Mynssen, C.M.; Bediaga, B.E.H.; Costa, D.P.; Dalcin, E.; Guimarães, E.F.; Martinell, G.; Silva, D.S.P.; Sylvestre, L.S.; Freitas, M.F.; Morim, M.P. \& Forzza, R.C. 2014. Catálogo das espécies de plantas vasculares e briófitas do Estado do Rio de Janeiro. Jardim Botânico do Rio de Janeiro. Available at $<$ http://florariojaneiro.jbrj.gov.br/>. Access on 6 May 2015.

Berry, P. 2015. Tackling a taxonomic giant: the genus Croton (Euphorbiaceae). Available at $<\mathrm{http}$ ://www. botany.wisc.edu/berry/projects/crotonFB/Pages/ Project\%20summary.html>. Access on 6 May 2015.

Bicudo, C.E.M. \& Menezes, M. 2010. As algas do Brasil. In: Forzza, R.C.; Baumgratz, J.F.A.; Bicudo, C.E.M.; Canhos, D.A.L.; Carvalho Jr., A.A.; Costa, A.F.; Costa, D.P.; Hopkins, M.; Leitman, P.M.; Lohmann, L.G.; Maia, L.C.; Martinelli, G.; Menezes, M.; Morim, M.P.; Nadruz-Coelho, M.A.; Peixoto, A.L.; Pirani, J.R.; Prado, J.; Queiroz, L.P.; Souza, V.C.; Stehmann, J.R.; Sylvestre, L.; Walter, B.M.T. \& Zappi, D. (eds.). Catálogo de plantas e fungos do Brasil. Vol. 1. Andrea Jakobsson Estúdio / Instituto de Pesquisas Jardim Botânico do Rio de Janeiro, Rio de Janeiro. Pp.49-60.

Brummitt, N.; Bachman, S.P.; Aletrari, E.; Chadburn, H.; Griffiths-Lee, J.; Lutz, M.; Moat, J.; Rivers, M.C.; Syfert, M.M. \& Nic Lughadha, E. 2015. The sampled red list index for plants, phase II : groundtruthing specimen-based conservation assessments. Philosophical Transactions of the Royal Society of London. (B.) 370: 20140015.

Daly, D.C. \& Silveira, M. 2009. Primeiro catálogo da flora do Acre, Brasil / First catalogue of the flora of Acre, Brazil. EDIUFAC, Rio Branco. 421p.

Dutra, V.F.; Alves-Araújo, A. \& Carrijo, T.T. 2015. Angiosperm Checklist of Espírito Santo: using electronic tools to improve the knowledge of an Atlantic Forest biodiversity hotspot Rodriguésia 66: 1145-1152.

Elliott, S.; Blakesley, D. \& Harwick, K. 2013. Restoring Tropical Forests - a practical guide. Royal Botanic Gardens, Kew. 344p.

Farinaccio, M.A.; Roque, F.O.; Graciolli, G.; Souza, P.R. \& Pinto, J.O.P. 2015 (in press). A flora no BiotaMS: montando o quebra-cabeça da biodiversidade de Mato Grosso do Sul. Iheringia. Série Botânica.

Forzza, R.C.; Baumgratz, J.F.A.; Bicudo, C.E.M.; Canhos, D.A.L.; Carvalho Jr., A.A.; Costa, A.F.; Costa, D.P.; Hopkins, M.; Leitman, P.M.; Lohmann, L.G.; Maia, L.C.; Martinelli, G.; Menezes, M.;
Morim, M.P.; Nadruz-Coelho, M.A.; Peixoto, A.L.; Pirani, J.R.; Prado, J.; Queiroz, L.P.; Souza, V.C.; Stehmann, J.R.; Sylvestre, L.; Walter, B.M.T. \& Zappi, D. (eds.). 2010. Catálogo de plantas e fungos do Brasil. 2 vols. Andrea Jakobsson Estúdio / Jardim Botânico do Rio de Janeiro, Rio de Janeiro. 1699p.

Forzza, R.C.; Baumgratz, J.F.A.; Bicudo, C.E.M.; Canhos, D.; Carvalho Jr., A.A.; Nadruz-Coelho, M.A.; Costa, A.F.; Costa, D.P.; Hopkins, M.; Leitman, P.M.; Lohmann, L.G.; Lughadha, E.N.; Maia, L.C.; Martinelli, G.; Menezes, M.; Morim, M.P.; Peixoto, A.L.; Pirani, J.R.; Prado, J.; Queiroz, L.P.; Souza, S.; Souza, V.C.; Stehmann, J.R.; Sylvestre, L.S.; Walter, B.M.T. \& Zappi, D.C. 2012. New Brazilian floristic list highlights conservation challenges. BioScience 62: 39-45.

Haase, R. \& Beck, S.G. 1989. Structure and composition of savanna vegetation in northern Bolivia: a preliminary report. Brittonia 41: 80-100.

Harley, R.M. \& Pastore, J.F. 2012. A generic revision and new combinations in the Hyptidinae (Lamiaceae), based on molecular and morphological evidence. Phytotaxa 58: 1-55.

Hopkins, M. 2003. Quantas espécies de plantas existem na Amazônia? In: Jardim, M.A.G.; Bastos, M.N.C. \& Santos, J.U.M. (eds.). Desafios da botânica brasileira no novo milênio: inventário, sistematização e conservação da diversidade vegetal. MPEG, UFRA, Embrapa, Belém. Pp.140-141.

Hopkins, M.J.G. 2007. Modelling the known and unknown plant biodiversity of the Amazon Basin. Journal of Biogeography 34: 1400-1411.

IBGE. 2004. Mapa de Biomas do Brasil, primeira aproximação. Available at $<$ http://www.ibge.gov. br>. Access on 15 March 2015.

IPNI. 2015. The international plant names index. Available at $<\mathrm{http}$ ://www.ipni.org $>$. Access on 20 March 2015.

Jørgensen, P.M.; Nee, M.H. \& Beck, S.G. (eds.). 2014. Catálogo de las plantas vasculares de Bolivia, Monographs in systematic botany from the Missouri Botanical Garden 127: 1-1744.

Kaehler, M.; Goldenberg, R.; Evangelista, P.H.L.; Ribas, O.S.; Vieira, A.O.S. \& Hatschbach, G.G. (eds.). 2014. Plantas vasculares do Paraná. Universidade Federal do Paraná, Curitiba. 198p.

Larrea-Alcázar, D.M.; Lópes, R.P.; Quintanilla, M. \& Vargas, A. 2010. Gap analysis of two savanna-type ecoregions: a two-scale floristic approach applied to the Llanos de Moxos and Beni Cerrado, Bolivia. Biodiversity and Conservation 19: 1769-1783.

Lista do Brasil. 2015. Lista de Espécies da Flora do Brasil. Jardim Botânico do Rio de Janeiro. Available at $<$ http://floradobrasil.jbrj.gov.br/>. Access on 18 April 2015.

Maia, L.C. \& Carvalho Jr, A. 2010. Os fungos do Brasil. In: Forzza, R.C.; Baumgratz, J.F.A.; Bicudo, 
C.E.M.; Canhos, D.A.L.; Carvalho Jr., A.A.; Costa, A.F.; Costa, D.P.; Hopkins, M.; Leitman, P.M.; Lohmann, L.G.; Maia, L.C.; Martinelli, G.; Menezes, M.; Morim, M.P.; Nadruz-Coelho, M.A.; Peixoto, A.L.; Pirani, J.R.; Prado, J.; Queiroz, L.P.; Souza, V.C.; Stehmann, J.R.; Sylvestre, L.; Walter, B.M.T. \& Zappi, D. (eds.). Catálogo de plantas e fungos do Brasil. Vol. 1. Andrea Jakobsson Estúdio / Jardim Botânico do Rio de Janeiro, Rio de Janeiro. Pp. 43-48.

Martinelli, G. 2007. Mountain biodiversity in Brazil. Revista Brasileira de Botânica 30: 587-597.

Martinelli, G. \& Moraes, M.A. (orgs.) 2013. Livro vermelho da flora do Brasil. Andrea Jakobsson / Jardim Botânico do Rio de Janeiro, Rio de Janeiro. $1100 p$.

Martius C.E.P.; Eschweiler, G.G. \& Nee ab Esenbeck, C.G. 1833. Flora brasiliensis, pars prior. Sumptibus J.G. Cottae, Stuttgartiae et Tubingen. $150 \mathrm{p}$.

MaToPiBa. 2015. The new agricultural frontier. Available at $<$ http://www.brazilintl.com/states/ mapitoba/mapitoba.htm>. Access on 6 May 2015.

Medeiros, H.; Obermüller, F.A.; Daly, D.C.; Silveira, M.; Castro, W. \& Forzza, R.C. 2014. Botanical advances in Southwestern Amazonia: The flora of Acre (Brazil) five years after the first Catalogue. Phytotaxa 177: 101-117.

Mittermeier, R.A.; Myers, N.; Thomsen, J.B.; Fonseca, G.A.B. \& Olivieri, S. 1998. Biodiversity hotspots and major tropical wilderness areas: approaches to setting conservation priorities. Conservation Biology 12: 516-520.

Mittermeier, R.A.; Robles-Gil, P.; Hoffmann, M.; Pilgrim, J.; Brooks, T.; Mittermeier, C.G.; Lamoreux, J. \& Fonseca, G.A.B. 2004. Hotspots revisited: Earth's biologically richest and most endangered terrestrial ecoregions. EMEX/ Agrupación Sierra Madre, Mexico City. 392p.

Moro, M.F.; Souza, V.C.; Oliveira-Filho, A.T.; Queiroz, L.P.; Fraga, C.N.; Rodal, M.J.N.; Araújo, F.S. \& Martins, F.R. 2012. Alienígenas na sala: o que fazer com espécies exóticas em trabalhos de taxonomia, florística e fitossociologia? Acta Botanica Brasilica 26: 981-989.

Myers, N.; Mittermeier, R.A.; Mittermeier, C.G.; Fonseca, G.A.B. \& Kent, J. 2000. Biodiversity hotspots for conservation priorities. Nature 403: 853-858.

Pastore, J.F.B.; Harley, R.M.; Forest, F.; Paton, A. \& van den Berg, C. 2011. Phylogeny of the subtribe Hyptidinae (Lamiaceae tribe Ocimeae) as inferred from nuclear and plastid DNA. Taxon 60: 13171329.

Pirani, J.R.; Sano, P.T.; Mello-Silva, R.; Menezes, N.L.; Giulietti, A.M.; Zappi, D.C. \& Jono, V.Y. (orgs.). 2015. Flora da Serra do Cipó, Minas Gerais.
Available at <http://www.ib.usp.br/botanica/ serradocipo>. Access 1 June 2015.

Prata, A.P.N.; Amaral, M.C.E.; Farias, M.C.V. \& Alves, M.V. 2013 (orgs.). Flora de Sergipe. Vol. 1. Gráfica e Editora Triunfo, Aracajú. 592p.

Ribeiro, J.E.L.S.; Hopkins, M.J.G.; Vicentini, A.; Sothers, C.A.; Costa, M.A.S.; Brito, J.M.; Souza, M.A.D.; Martins, L.H.P.; Lohmann, L.G.; Assunção, P.A.C.L.; Pereira, E.C.; Silva, C.F.; Mesquita, M.R. \& Procópio, L.C. 1999. Flora da Reserva Ducke, Guia de identificação. DFID \& INPA, Manaus. 800 p.

Sarmiento, G. 1983. The savannas of Tropical America. In: Bourliére, F. (ed.). Ecosystems of the world 13: tropical savannas. Elsevier Scientific Publishing Company, Amsterdan, Oxford, New York. Pp. 245-288.

Siqueira Filho, J.A. (org.). 2012. A flora das Caatingas do Rio São Francisco: história natural e conservação. Andrea Jakobsson Estúdio, Rio de Janeiro. 552p.

Souza, V.C. 2010. As gimnospermas do Brasil. In: Forzza, R.C.; Baumgratz, J.F.A.; Bicudo, C.E.M.; Canhos, D.A.L.; Carvalho Jr., A.A.; Costa, A.F.; Costa, D.P.; Hopkins, M.; Leitman, P.M.; Lohmann, L.G.; Maia, L.C.; Martinelli, G.; Menezes, M.; Morim, M.P.; Nadruz-Coelho, M.A.; Peixoto, A.L.; Pirani, J.R.; Prado, J.; Queiroz, L.P.; Souza, V.C.; Stehmann, J.R.; Sylvestre, L.; Walter, B.M.T. \& Zappi, D. (eds.). Catálogo de plantas e fungos do Brasil. Vol.1. Andrea Jakobsson Estúdio / Instituto de Pesquisas Jardim Botânico do Rio de Janeiro, Rio de Janeiro. Pp.75-77.

Sobral, M. \& Stehmann, J.R. 2009. An analysis of new Angiosperm species discoveries in Brazil (1990 2006). Taxon 58: 227-232.

ter Steege, H.; Pitman, N.C.A.; Sabatier, D.; Baraloto, C.; Salomao, R.P.; Guevara, J.E.; Phillips, O.L.; Castilho, C.V.; Magnusson, W.E.; Molino, J.-F.; Monteagudo, A.; Nunez Vargas, P.; Carlos Montero, J.; Feldpausch, T.R.; Coronado, E.N.H.; Killeen, T.J.; Mostacedo, B.; Vasquez, R.; Assis, R.L.; Terborgh, J.; Wittmann, F.; Andrade, A.; Laurance, W.F.; Laurance, S.G.W.; Marimon, B.S.; Marimon, B.-H.; Guimaraes Vieira, I.C.; Amaral, I.L.; Brienen, R.; Castellanos, H.; Cardenas Lopez, D.; Duivenvoorden, J.F.; Mogollon, H.F.; de Almeida Matos, F.D.; Davila, N.; Garcia-Villacorta, R.; Stevenson Diaz, P.R.; Costa, F.; Emilio, T.; Levis, C.; Schietti, J.; Souza, P.; Alonso, A.; Dallmeier, F.; Duque Montoya, A.J.; Fernandez Piedade, M.T.; Araujo-Murakami, A.; Arroyo, L.; Gribel, R.; Fine, P.V.A.; Peres, C.A.; Toledo, M.; Gerardo, A.A.C.; Baker, T.R.; Ceron, C.; Engel, J.; Henkel, T.W.; Maas, P.; Petronelli, P.; Stropp, J.; Eugene Zartman, C.; Daly, D.; Neill, D.; Silveira, M.; Rios Paredes, M.; Chave, J., de Andrade Lima, D.; Jorgensen, P.M.; Fuentes, A.; Schoengart, J.; Cornejo Valverde, 
F.; Di Fiore, A.; Jimenez, E.M.; Penuela Mora, M.C.; Fernando Phillips, J.; Rivas, G.; van Andel, T.R.; von Hildebrand, P.; Hoffman, B.; Zent, E.L.; Malhi, Y.; Prieto, A.; Rudas, A.; Ruschell, A.R.; Silva, N.; Vos, V.; Zent, S.; Oliveira, A.A.; Cano Schutz, A.; Gonzales, T.; Nascimento, M.T.; Ramirez-Angulo, H.; Sierra, R.; Tirado, M.; Umana Medina, M.N.; van der Heijden, G.; Vela, C.I.A.; Vilanova Torre, E.; Vriesendorp, C.; Wang, O.; Young, K.R.; Baider, C.; Balslev, H.; Ferreira, C.; Mesones, I.; Torres-Lezama, A.; Urrego Giraldo, L.E.; Zagt, R.; Alexiades, M.N.; Hernandez, L.; Huamantupa-Chuquimaco, I.; Milliken, W.; Palacios Cuenca, W.; Pauletto, D.; Valderrama Sandoval, E.; Valenzuela Gamarra, L.; Dexter, K.G. \& Feeley, K. 2013. Hyperdominance in the Amazonian tree flora. Science 342: 325. DOI: 10.1126/science. 1243092 .
Specieslink. 2015. Indicadores. Available at $<\mathrm{http}: / /$ splink.cria.org.br/indicators/index?setlang=pt. $>$. Acess on 27 May 2015.

Urban, I. 1906. Index Familiarum. In: Martius, C.P.F. von; Eichler, A.W; Urban, I. \& Oldenbourg, R. Flora brasiliensis. Monachii. Vol 1, pars 1, pp. 239-268.

Zappi, D.C.; Taylor, N.P. \& Larocca, J. 2012. A riqueza das Cactaceae no Brasil. In: Ribeiro-Silva, S.; Zappi, D.C.; Taylor, N.P. \& Machado, M.C. (eds.) Plano de ação nacional para a conservação das cactáceas. ICMBio, Brasília. Pp.15-26.

Zuloaga, F.O; Morrone, O. \& Belgrano, M.J. 2008. Catálogo de las plantas vasculares del ConoSur (Argentina, Sur de Brasil, Chile, Paraguay y Uruguay). 3 vols. Monographs in Systematic Botany from the Missouri Botanical Garden 107: 1-3486. 
